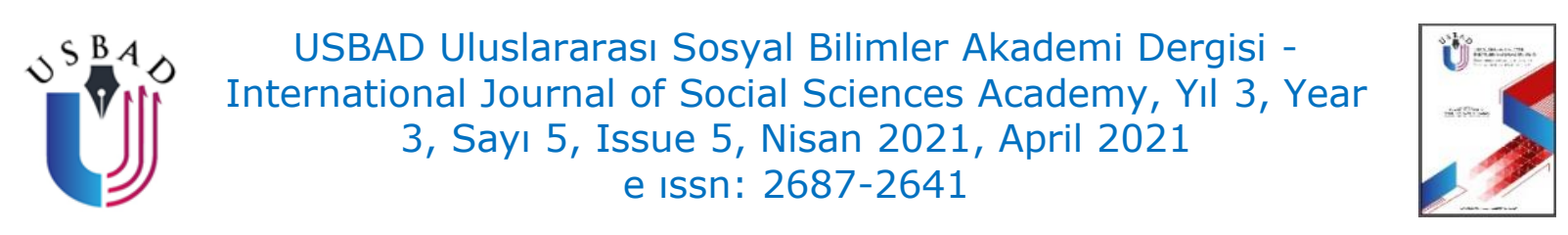

\title{
İLETİŞİM BİLİMİNDE DİJİTAL OYUNLAR ÜZERİNE YAPILAN ÇALIŞMALARIN BETİMSEL ANALİİ
}

A DESCRIPTIVE ANALYSIS OF STUDIES ON DIGITAL GAMES IN COMMUNICATION SCIENCE

\author{
Alp Eren ERBAY \\ Doktora Öğrencisi, Medya ve İletişim Çalışmaları Programı, İletişim Bilimi ve \\ İnternet Enstitüsü, İstanbul Ticaret Üniversitesi, İstanbul/Türkiye. \\ PhD student, Media and Communication Studies, Institue of Communication \\ Science and the Internet, İstanbul/Turkey. \\ aeerbay@ticaret.edu.tr \\ ORCID ID: 0000-0001-7424-759X

\section{Makale bilgisi | Article Information} \\ DOI: $10.47994 /$ usbad. 817988 \\ Makale Türü / Article Type: Araştırma Makalesi / Research Article \\ Geliş Tarihi / Date Received: 29.10.2020 \\ Kabul Tarihi / Date Accepted: 20.03.2021 \\ Yayın Tarihi / Date Published: 20.04.2021 \\ Yayın Sezonu / Pub Date Season: Nisan / April
}

Bu Makaleye Atıf İçin / To Cite This Article: Erbay, A. E. (2021). İletişim Biliminde Dijital Oyunlar Üzerine Yapılan Çalışmaların Betimsel Analizi. USBAD Uluslararası Sosyal Bilimler Akademi Dergisi 3(5), 519-556.

İntihal: Bu makale intihal.net yazılımınca taranmıştır. İntihal tespit edilmemiştir. Plagiarism: This article has been scanned by intihal.net. No plagiarism detected.

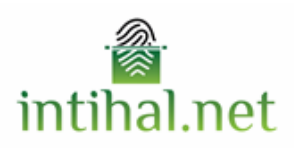

İletişim: Web: https://dergipark.org.tr/tr/pub/usbad mail: usbaddergi@gmail.com 
Öz: Dijital oyunlar yaşamda giderek artan bir öneme sahip olmakta, bu süreçte farklı disiplinler tarafından akademik çalışmalara konu olmaktadır. Literatürde dijital oyunların hangi disiplinlerle, hangi kuramsal yaklaşım ve kavramsal çerçevelerle, hangi yöntemlerle incelenmesi gerektiğine dair süregelen bir fikir uyuşmazlığı bulunmaktadır. Bu çalışmada araştırma kapsamındaki tezler, araştırmacının oluşturduğu "21 başlıklı tez analiz tablosu" ile nitel olarak incelenmiş ve betimsel analiz uygulanmıştır. Sonuç olarak tezlerin odaklandığı konular kategorize edilmiş, bilimsel disiplinleri, kuramları ve yöntemleri tanımlanmış, genel eğilimler açıklanmıştır. Elde edilen bulgular, dijital oyunlara ilişkin gerçekleştirilecek yeni çalışmalarda temel ya da örnek oluşturabileceği gibi; konu, disiplin, kuram, kavramsal çerçeve ve yöntem bağlamında yeni yönelimler oluşmasında cesaretlendirici ve ilham verici olabilir.

Anahtar Kelimeler: Dijital Oyunlar, Video Oyunları, İletişim Bilimi, Akademik Çalışmalar, Betimsel Analiz

Abstract: Digital games have increasing importance in life, and along with this process, they became subject to academic studies in different disciplines. There is an ongoing disagreement about which scientific disciplines, theoretical approaches, conceptual frameworks, and methods should be used by academicians while examining digital games. Theses within the scope of this study inspected qualitatively with the "21 titled thesis analysis table" created by the researcher and descriptive analysis method applied to the output. The topics the theses have focused on categorized, their scientific disciplines, theories, and the research methods are defined, and general trends are explained. The findings of this study can serve as a basis or an example in new researches on digital games; It can be encouraging and inspiring in the formation of trends in the context of the subject, discipline, theory, conceptual framework, and method.

Keywords: Digital Games, Video Games, Communication Science, Academic Studies, Descriptive Analysis

\section{GİRİ̧}

Dijital oyunlar politik, ekonomik, sosyolojik ve kültürel işlevleri sebebiyle giderek artan bir önemle hayatımızda yer etmekte, bu sürece paralel olarak da farklı disiplinler tarafından araştırmalara konu edilmektedir. Kitle ve bireyler arası iletişimi sağlayan, serbest zaman ve eğlence aktivitesi olarak üretilip oynanan, kullanılan görsel ve işitsel öğelerle sanat olarak değerlendirilebilen, eğitim ya da iş amacıyla kullanılabilen dijital oyunlar; yapısal özellikleriyle haz ve mutluluk hormonlarını tetiklemekte, sahip olduğu senaryo ve anlatılarla yoğun ideolojik mesajlar içerebilmektedir. Dijital oyunlar, yüksek etkileşimle 
oyuncuyu aktif konuma getirmekte, böylece iletişim sürecini özel ve estetik bir "deneyime" dönüştürmektedir.

\section{GELENEKSEL VE DİJİTAL OYUN KAVRAMI}

İnsanlar ve hayvanlar doğdukları andan itibaren bedenlerini, zihinlerini, yaşadıkları dünyayı ve sosyal ilişkilerini keşfetmek, geliştirmek için oyun oynamışlardır. İnsan doğasının ve kültürünün en eski edimlerinden biri olmasının yanında, tarihsel sıralama içerisinde değerlendirilecek olursa, oyun kavramı kültürün oluşmasından çok önce hayatımızda yer etmiştir; Huizinga'nın dediği gibi, "Oyun, kültürden de eskidir" (Huizinga, 2018: 8) ve oyun belirli bir mekân ve zaman içerisinde, gönüllü olarak, kuralları belirlenmiş yeni bir dünyada heyecan içerisinde eğlenilerek yapılan aktivitedir (Huizinga, 2018: 40).

Caillois ise oyunu: "Özgür, gönüllü, zaman ve uzam bakımından ayrı, belirsiz, kurallı ve inandırıcı özelliği olan etkinlikler" olarak tanımlamıştır (Caillois, 2006: 128). Karl Gross ise oyunu tanımlarken onun eğitici niteliklerine vurgu yapmaktadır; oyunlar "İçgüdüsel ve eğitsel deneyimin bir parçasıdır. Oyun aracılığıyla birey yaşamın daha sonraki dönemlerinde izlenecek şeylerin deneyimini yaşar" (İgit, 2019: 33). Şentürk ve Aktaş oyunun "(...) bireylere çeşitli zihinsel becerilerin kazandırılması için son derece uygun bir ortam (...)" olduğunu belirterek eğitici niteliğini vurgulamaktadır (Şentürk ve Aktaş, 2014).

Antik Mısır'da MÖ 3100 yılında oynanan "senet" oyunundan, MÖ. 600 yılında Hindistan'da oynanan satranç benzeri oyuna, Antik Yunan'daki anlatı temelli oyunlardan, Antik Roma'daki gladyatör oyunlarına varana dek oyun, tüm kültürlerde ve zamanlarda, kendine önemli bir yer bulmuştur (Sezen ve Sezen, 2011: 251). Oyun tarihin tüm aşamalarında bulunmaktadır; nitekim oyunun kendisi tüm zamanı kapsayan bir eylemdir. Arnold bu durumu açıklarken; "Oyun geçmişle ilintilidir, şimdiki zamanın eğlence, gelenek ve tabuları için ortam oluşturur, gelecek için de önemli bir katılımdır" ifadelerini kullanmaktadır (Arnold, 1995: 9).

Teknolojinin gelişmesiyle; oyunlarda kullanılan araçlar tahta ya da taş gibi materyallerden, estetik sahibi oyuncaklara dönüşmüştür. Oyun araçları ya da oyunların kendisi daha sonra mekanikleşmiş, elektronikleşmiş, yakın dönemde de analog ve dijital bilgisayar teknolojileriyle son halini almıştır.

Dijital oyunlar onlar üzerine araştırma yapan pek çok kişi tarafından tanımlanmıştır. Pek çok disiplin tarafından incelenen bu fenomen üzerinde 
uzlaşılmış tek bir tanım bulunmamaktadır. Arjoranta, oyun tanımlarına dair bir yaklaşım sunduğu makalesinde oyunların hermeneutik anlam bilim teorisinde tanımlanması ve her defasında yeniden tanımlanması gerektiğini söylemektedir. Böylece daha önce problemli olan tanımların üstesinden gelinebilir, yeni bakış açıları kazanmak mümkün olur (Arjoranta, 2014).

$\mathrm{Bu}$ yaklaşımdan hareketle, bu çalışmanın başında dijital oyunları; sayısal bilgisayar teknolojileriyle üretilen görsel ve işitsel öğelerin belirli zaman, alan ve kurallar dahilinde, çeşitli donanımlar aracılığıyla hem sunulduğu hem de etkileşim yoluyla kontrol edilmesine imkân tanındığı simülasyonlar olarak tanımlamak mümkündür.

Juul, klasik oyun modelini anlattığı makalesinde bir şeyin oyun olması için sahip olması gereken 6 özelliği; "kurallar, sonuç, hedefler, etkileşim, hedef-kural-oyun dünyasının ilişkisi, gerçek dünyadan ayrıklık, gönüllü olma, az efor gerektirme, sosyal gruplar ve kurgu" olarak sıralamıştır. Dijital oyunlarda da bu özellikler var olduğunu belirtir; ancak özellikler değişkenlik gösterebilir (Juul, 2003).

Elektronik ve dijital teknolojileri kullanarak bir ekran ve kontrolcüler vasıtasıyla oynanan dijital oyunlar, elbette geleneksel oyunlardan en başta teknik anlamda farklıdır. En önemli fark ise bir iletişim süreci olan geleneksel oyunun, artık yeni medya özelliklerini barındırmasından kaynaklanmaktadır (Binark ve Bayraktutan-Sütçü, 2008: 45).

Garrelts, dijital oyunlar üzerine akademik çalışmalar yapanların karşılaştığı ilk sorunun, çalışma nesnesini isimlendirmek olduğunu belirtir. Özellikle kullanılan teknolojiden ötürü, donanıma göre farklı isimler kullanılmaktadır (Garrelts, 2005). Dijital oyunlar, bir üst kavram olarak kullanılır; video oyunları, bilgisayar oyunları, konsol oyunları, mobil oyunlar gibi kavramları içermektedir (Binark ve Bayraktutan-Sütçü, 2008: 42-43). Aarseth, bilgisayar oyunları kavramını zayıf bulmaktadır. Bu isimlendirmenin, bilgisayarlı oyuncaklar ya da dijital rakipli satranç setleri gibi oyunları da kapsayacağından yola çıkarak, dijital oyunlar olarak adlandırılan oyunların "sanal ortamlardaki oyunlar" olarak isimlendirilebileceğini öne sürer (Aarseth, 2003: 2).

\subsection{Dijital Oyunların Tarihsel Gelişimi}

Geleneksel oyundan, modern zamanların dijital oyunlarına geçiş aşamasındaki ilk oyunlara dair kesin kronolojik bir sıralama yapmak 
güçtür. Bu güçlük, çoğunlukla kullanılan teknolojinin yarattığı kavram karmaşasından kaynaklanmaktadır.

Analog bilgisayar teknolojisini kullanan ilk oyunlardan biri 1958 yapımı "Tennis for Two" (Kline vd., 2003: 92) ve dijital bilgisayar ile yapılan ilk oyun; 1962 yapımı "Spacewar" olarak kabul edilmektedir (Binark ve Bayraktutan-Sütçü, 2008: 52). İlk ev tipi oyun konsolu ise "Magnavox Odyssey" ismiyle 1972 yılında piyasaya sürülmüştür (Wolf, 2012: 3). Dijital oyunların ne derece büyük popülerlik ve satış bağlamında ne derece büyük başarı elde edebileceğini ispatlayan oyun, 1978 yapımı "Space Inviders" olmuştur (Tezel, 2019: 29). ABD oyun piyasasındaki doygunluktan kaynaklanan, "the crash" ismi verilen ve 1983 yılında meydana gelen büyük çöküş (Wolf, 2012: 87, 88), 1985 Yllında Nintendo Entertainment System (NES) ismi verilen oldukça popüler olan ev tipi oyun konsolunun yakaladığı başarı ile son bulmuştur (Brookey, 2010). Grafiklerin 3 boyutlu hale gelmesiyle "Wolfenstein 3D (1992), Doom (1993), Quake (1996), Half Life (1998)" gibi oldukça başarılı nişancı oyunları piyasada ses getirmiştir (Wills, 2019). Sony, oyun sektöründe oldukça kuvvetli bir noktadayken, 2000 yılında Playstation 2 isimli video oyun konsolunu çıkarmıştır. Konsol, tüm zamanların en çok satılan oyun konsolu olmuştur (Lupton, 2018) ve sonrasında Microsoft, Nintendo gibi Sayfa | 523 firmalar da oyun konsol serileri çıkartarak oyun piyasasında önemli yer etmişlerdir (history.com, 2019)

\subsection{Son Dönemde Dijital Oyunlar}

Dijital oyun endüstrisinin ve oyunların gelişimi devam etmektedir. Dijital oyun sektörünün ciddi bir kültür endüstrisine dönüştüğünü söylemek mümkündür. Donanımlar ve yazılım olarak oyunların kendileri ayrı satılmakta, oyunların ek paketleri, karakterler, çeşitli oyun eşyaları ve özellikler ayrıca satılabilmektedir. Steam, Origin, Playstation Store, GOG, Ubisoft UPlay, Epic Games, Microsoft Store, Blizzard gibi oyun sektöründe önemli yerleri olan oyun platformları, çeşitli abonelik sistemleri ile dijital oyun ekonomisinde farklılıklar yaratmaktadır. Dijital oyun dünyası, yalnızca oyun ve ona dair ürünlerin satıldığı bir sektörden daha fazlası olarak; e-spor ve oyun yayıncılığı gibi, ayrı incelemelere intiyaç duyulacak kavramlar ve sektörler yaratmıştır.

Kültür endüstrisinin bir özelliği olarak, dijital oyunlar ve sektör sürekli yenilenmekte ve gelişmektedir. 2020 Yılında dünyayı etkisi altına alan Covid 19 salgını kaynaklı karantina dönemi, tüm oyun segmentlerinin gelirlerinde artışa sebep olmuştur (Newzoo, 2019). "Oyunun limiti yok" 
sloganıyla 2020 yılında çıkacak olan Sony'nin Playstation 5'i, her zamankinden daha gelişmiş görseller ve sesler, dokunmatik geri bildirimler (Playstation, 2020), Microsoft'un Xbox Series X isimli konsolu, 4k çözünürlük, yüksek kare hızı, 3 boyutlu ses gibi donanımsal özellikler sunmaktadır (Xbox, 2020). Sanal gerçeklik, artırılmış gerçeklik oyunları; yüksek bütçe gerektiren cihazlara sahip olanların lüksü olmaktan, kitlelere yayılma eğilimine geçmişlerdir. ABD'de anket uygulanan kişilerin $\% 25^{\prime} \mathrm{i}$ artırılmış gerçeklik oyunlarını, \%28'i sanal gerçeklik oyunlarını deneyimlemiştir (Newzoo, 2019).

Bulut tabanlı oyun sistemi, dijital oyun fenomeninde önemli bir gelişme yaratmıştır. Kullanıcılar özel ve yüksek donanımlı cihazlara sahip olmadan, istedikleri ekrandan, yüksek internet hızı vasıtasıyla abone oldukları sunuculara bağlanıp oyun oynayabilmektedirler (Stadia, 2020). Stadia, GeForce Now, Playstation Now, Microsoft Azure gibi sistemler, oyun dünyasında gelecekte önemli değiş̧iklikler yapmaya aday olabilirler (Dutta, 2020).

2020 yılı itibariyle 7,79 milyar olan dünya nüfusunun (Worldometer, 2020), 2,69 milyarı aktif olarak dijital oyun oynamaktadır (Statista, 2020). Tüm dünyada dijital oyunlar marketi, 159,3 milyar dolarlık büyüklüğe sahiptir (Newzoo, 2020).

Yine 2020 yılı itibariyle ABD'deki hanelerin \%75'inde en az bir video oyun oynatıcısı bulunmakta; 214,4 milyon kişi oyun oynamaktadır. Bu kişilerin \%38'i, 18-34 yaş aralığında, \%26'sı 35-54 yaş aralığında ve \%21'i 18 yaşından küçüktür (Entertainment Software Association, 2020).

Türkiye'de 2019 yılı verilerine göre, 32 milyondan fazla insanın oyun oynadığı ve toplam oyun hasılatının 830 milyon dolar olduğu bilinmektedir. Toplam oyuncuların \%34,95'i 25-34, \%28,60'ı 35-44 ve \%21,87'si 18-24 yaş aralığındayken, kalan 14,57'lik yüzdelik dilim 45 yaşından büyüktür. Tüm oyuncuların \%57,2'si erkek, \%42,8'i kadındır (Gaming in Turkey, 2019). Veriler toplumda var olan algıların tersine, yetişkinlerin daha çok oyun oynadığını, kadınların da neredeyse erkekler kadar oyun oynadığını göstermektedir. Dijital oyunların iyi anlaşılması, işlevlerinin faydalı olarak kullanılması ve artırılması için bilimsel çalışmalara olan ihtiyaç giderek artmaktadır. 


\section{DİJİTAL OYUNLARA İLİŞKİN BİLİMSEL YAKLAŞIMLAR}

Dijital oyunların gelişmesine ve popülerleşmesine paralel olarak, dijital oyunlara ilişkin akademik çalışmalar da artmış ve çeşitlilik göstermiştir.

Küresel akademik atıf veri tabanı Web of Science (bilim ağı) üzerinde, "digital games" ve "video games" anahtar kelimeleri ile arama yapıldığında; 1979-2020 yılları arasındaki 27,471 bilimsel çalışma ile karşılaşılmaktadır. En çok çalışma sırasıyla; bilgisayar bilimi, eğitim, mühendislik, psikoloji ve iletişim alanında gerçekleştirilmiştir. En çok çalışmayı sırasıyla; ABD, İngiltere, Kanada, İspanya ve Almanya gerçekleştirmiştir. Türkiye, söz konusu sıralamada 22. sırada bulunarak, alandaki toplam bilimsel çalışmaların \%1,2'sini gerçekleştirmiştir (Web of Science, 2020).

\subsection{Dijital Oyunlara İlişkin Bilimsel Çalışmalarda Disiplin Tartışmaları}

Dijital oyunların farklı disiplinler tarafından farklı araştırma odaklarında incelenmesi, zaman içerisinde kuramsal ve metodolojik bir uzlaşmazlık doğurmuştur. Çatışma dijital oyunların zaten mevcut olan disiplinlerle, özellikle anlatım bilimi (narratology) ile incelenebileceğini düşünenlerle; oyunların yapısal ve biçimsel özelliklerine odaklanıp, onları başı başına bir disiplin içerisinde "oyun" olarak incelenmesi gerektiğini düşünen, ludoloji disiplini (ludology) alanında çalışanlar arasında yaşanmıştır.

Janet Murray, elektronik olsun ya da olmasın, her oyunun bir drama, yani anlatının bir alt türü olarak değerlendirilebileceğini belirtmiştir (Murray, 2016). Murray, ludolojistleri oyunları kültürel tarihten ayırmakla suçlamaktadır (Murray, 2005). Ona göre oyunlar kültürün bir parçası oldukları için pekâlâ bir roman ya da sinema filmi gibi analiz edilebilirler (Murray, 2016: 144). Benzer görüşteki Laurel ise bilgisayarları tiyatroya, insanları da kullanıc ve seyirciye benzetmektedir (Karadeniz, 2017: 61). Aristo'nun drama yaklaşımını bilgisayarlara uygulamaya çalışarak interaktif drama teorisi üretir (Işığan, 2012).

Gonzalo Frasca ise 1999 yılında yayınlanan makalesinde edebiyat teorisi ve anlatım biliminin oyunları anlamada yardımcı olduğunu, oyunların anlatılardaki bazı özellikleri içerdiğini kabul etmektedir ancak ona göre oyunları yalnızca anlatım bilimi ile analiz etmek eksik bir 
yaklaşımdır, bunu tamamlamak için onları "oyun" olarak analiz etmek gerekir (Frasca, 1999).

Oyunların geleneksel anlatılardan farklı olduğunu öne süren Espen Aarseth, oyunların estetik ve sosyalleşme özellikleriyle sinema ya da romana kıyasla çok yüksek etkileşime sahip olduklarını belirtir. Ona göre oyunları Hollywood yapımı sinemalar gibi klasik anlatı olarak görmek, onların sosyo-estetik yönünü göz ardı etmektir. Oyunlar, bilişsel ve iletişimsel yapıları olan simülasyonlar olarak anlatılardan farklıdır. Bu sebeplerle tamamen yeni bir disiplin yaratılması gerektiğini savunmaktadır (Aarseth, Computer Game Studies, Year One, 2001). Bu noktada Aarseth'in, dijital oyunları incelemeyi tek bir alanın; "oyun çalışmalarının" egemenliği altına almaya çalıştığı düşünülmemelidir. Onun karşı çıktığı, oyunların yalnız "anlatı" olarak ele alınamayacağıdır.

Ludolojist Jesper Juul'a göre oyunlar; filmler ve romanlar gibi anlatılarla aynı ekoloji içerisinde değildir. Oyunlarda zaman, anlatılardaki zamandan farklı işlemektedir. Klasik anlatılardaki okuyucu ya da izleyici ile, hikâye arasındaki ilişki, oyuncu ve oyunun dünyası arasındaki ilişkiden farklıdır (Juul, 2001). Dijital oyunlar anlatıların aksine performans odaklıdır ve bu performans sergilenirken her defasında farklı tarzlar sergilenebilir (Juul, 1998).

Eskelinen, klasik anlatılarda hikâyenin tamamının okunması ya da izlenmesi gerektiğini, oysa oyunlarda ilerlemek için farklı yolların tercih edilebileceğini hatta oyunun bazı kısımlarının oynanmama özgürlüğü sunduğundan bahsetmektedir. Bir şeyi anlatı yapmak için salt hikâyenin yeterli olmadığını vurgulamakta ve hikâye bileşenlerinin hepsinin oyunlarda var olmadığını öne sürmektedir (Eskelinen, 2001).

Garrelts, modern dijital oyunları bir anlam içermek zorunda olmayan "karmaşık medya metinleri" olarak görür ve oyun çalışmaları alanını bu oyunları incelemek konusunda yetersiz görmektedir. O'na göre oyun çalışmaları, oyuncuları, iletileri yorumlayarak alan aktif özneler değil, pasif araçlar olarak gördüğü için sorun yaşanmaktadır (Garrelts, 2005).

Boellstroff, dijital oyun çalışmalarının her zaman disiplinler arası olduğunu, farklı disiplinlerden alınan kuramsal yaklaşımların ve metotların oyun çalışmaları için birleştirilerek kullanılabileceğini, ancak oyunları anlamada en uygun disiplin olarak antropolojiden yararlanılabileceğini belirtmektedir (Boellstorff, 2006: 30). 
Nieborg ve Hermes oyun çalışmalarının disiplinler arası olduğunu, kültürel çalışmalar ile incelenebileceğini ve ekonomi politik bakış açısının oyun çalışmalarında sorgulanması gerektiğini düşünürler (Nieborg ve Hermes, 2008).

Bayraktutan-Sütçü disiplinler arası bir yaklaşımı önermektedir; ona göre önemli olan araştırılacak konunun belirlenmesi ve analiz odağının sorgulanmasıdır. Her araştırmacı kendi yaklaşımına göre bir yöntem belirleyebilir, dijital oyun araştırmalarının tek bir disiplinin alanı olmaması gerektiğini savunur (Bayraktutan Sütçü, 2009: 345-347).

\subsection{Dijital Oyunlara İlişkin Bilimsel Çalışmalarda Önerilen Yöntemler}

Konzack dijital oyunları incelemek için 7 katmanlı bir analiz yöntemi geliştirmiştir. Oyunları donanım, program kodu, işlevsellik, oynanış, referans derecesi ve sosyo-kültürel katmanlarına ayırıp inceleyerek teknik, estetik ve sosyo kültürel bağlamda bütün olarak analiz etmektedir (Konzack, 2002).

Aaerseth ise dijital oyunların; oynanış (oyuncu eylemleri), oyun yapısı (kurallar) ve oyun dünyası (kurgusal içerik, görsel ve işitsel içerikler) bağlamında, 3 katmanda incelenebildiği bir yöntem sunmaktadır. Bu Sayfa|527 katmanlar birbiriyle ilişkilidir, kendi içlerinde alt katmanlara ayrılırlar ve çeşitli oyunlarda katmanların önemi değişebilir (Aarseth, 2003).

Lankoski ve Björk, dijital oyunları inceleyen nitel araştırmalarda; oyunların temel bileşenlerini ve kurallarını analiz edip açıklayan "yapı analizi", oyunlarda zamanı tanımlama ve analiz etmeye yarayan "zaman analizi" ve "oyunları bilgi sistemleri olarak ele alan analiz" önermektedir. Oyun oynama edimi ve oyuncular üzerine nitel araştırmalar içinse etnografi, derinlemesine görüşme, uyarılmış hatırlama ve odak grup çalışmaları gibi geleneksel yöntemleri önerirler (Lankoski ve Björk, 2015: $6,7)$.

Landers ve Bauer, nitel araştırmaların ancak insanın rasyonel davranabilme kabiliyeti kapsamında nitelikli olabildiğini, nicel yaklaşımların bu soruna bir çözüm ürettiğini belirterek istatiksel yöntemleri; psikometri ve klasik test teorisini önermektedir (Landers ve Bauer, 2015: 151, 152).

Video oyunlarının işitsel ve görsel içeriklerinin nicel analizi ile oyuncuların deneyimlerine ilişkin iç görüler çıkaran yöntemler (Marczak ve Schott, 2015), oyuncuların oyun deneyimine dair ayrıntılı istatistiklerin kullanıldığı oynanış verilerini görselleştirme yöntemi (Wallner ve Kriglstein, 
2015), oyunları psikofizyoloji çalışmaları için bir uyaran olarak kullanan yöntemler ve yapısal eşitlik modeli (Lankoski ve Björk, 2015) gibi yöntemler, nicel araştırmalarla oyun, oyuncu ve ikisi arasındaki ilişkiye dair araştırmalarda kullanılmaktadır.

Lieberoth ve Roepstroff'a göre ise, bir oyunun yalnız bir araştırma yöntemiyle incelenmesi, onun geniş evreninin ve etkilerinin yalnız küçük bir kısmını anlamaya yardımcı olur. Özellikle hem oyun hem de oyuncuyu araştırma odağına alan çalışmalarda karma yöntemlerin kullanmasını önerirler (Lieberoth ve Roepstorff, 2015).

\subsection{Dijital Oyunlara İlişkin Türkiye'deki Bilimsel Çalışmalar}

Yükseköğretim Kurumu Başkanlığı Tez Merkezi'nin online veri tabanında; "dijital oyun, video oyunu, bilgisayar oyunu" ve "mobil oyun, konsol oyunu" anahtar kelimeleri tüm arama alanlarında aratıldığında; 358 yayımlanmış teze ulaşılmaktadır (Yükseköğretim Kurulu Başkanlığı, 2020). Arama sonuçlarında, birden fazla anahtar kelime barındırması sebebiyle yinelenen tezler çıkarıldığında Türkiye'de üst kavram olarak dijital oyunlara dair (diğer anahtar kelimeleri de içeren) 353 teze ulaşılmıştır. Tezlerin 283 tanesi yüksek lisans, 53 tanesi doktora, 12 tanesi tıpta yeterlilik, 5 tanesi de sanatta yeterlilik tezidir. Tablo 1 'de ulaşılan tezlerin yıllara ve konulara göre sayımından elde edilen veriler gösterilmiştir.

\begin{tabular}{lc|lc|cc} 
Konu & $\begin{array}{c}\text { Tez } \\
\text { Sayısı }\end{array}$ & Konu & $\begin{array}{c}\text { Tez } \\
\text { Sayısı }\end{array}$ & Yıl & $\begin{array}{c}\text { Tez } \\
\text { Sayısı }\end{array}$ \\
Eğitim ve Öğretim & 114 & $\begin{array}{l}\text { Endüstri Ürünleri } \\
\text { Tasarımı }\end{array}$ & 4 & 1991 & 1 \\
Psikoloji & 53 & $\begin{array}{l}\text { Sahne ve Görüntü } \\
\text { Sanatları }\end{array}$ & 4 & 1996 & 1 \\
İletişim Bilimleri & 42 & Gazetecilik & 3 & 1997 & 1 \\
Güzel Sanatlar & 31 & Adli Tıp & 2 & 2004 & 1 \\
Bilgisayar Müh. & 25 & Elektrik Elektronik & 2 & 2005 & 3 \\
Bilim ve Teknoloji & 14 & Müh. & 2 & 2006 & 3 \\
Mimarlık & 14 & Müh. & 2 & 2007 & 7 \\
Sporstri ve Endüstri & 14 & Matematik & 2008 & 4 \\
Hemşirelik & 13 & Nöroloji & 2009 & 7 \\
Radyo-Televizyon & 13 & Sosyal Hizmetler & 2010 & 7
\end{tabular}




\begin{tabular}{|c|c|c|c|c|}
\hline Sosyoloji & 12 & Aile Hekimliği & 1 & 2011 \\
\hline İşletme & 11 & $\begin{array}{l}\text { Anestezi ve } \\
\text { Reanimasyon }\end{array}$ & 1 & 2012 \\
\hline Halk Sağlığı & 6 & Antropoloji & 1 & 2013 \\
\hline Halkla İliş̧kiler & 6 & Biyoloji & 1 & 2014 \\
\hline Reklamcılık & 6 & Onkoloji & 1 & 2015 \\
\hline $\begin{array}{l}\text { Çocuk Sağlığı ve } \\
\text { Hastalıkları }\end{array}$ & 5 & Siyasal Bilimler & 1 & 2016 \\
\hline \multirow[t]{4}{*}{ Psikiyatri } & 5 & $\begin{array}{l}\text { Şehircilik ve Bölge } \\
\text { Planlama }\end{array}$ & 1 & 2017 \\
\hline & & & & 2018 \\
\hline & & & & 2019 \\
\hline & & & & 2020 \\
\hline
\end{tabular}

Tablo 1: Konulara ve Yıllara Göre Yayımlanmış Tez Sayısı (Yükseköğretim Kurulu, 2020)

YÖK Tez Merkezi'nde "Alan" yerine "Konu" ifadesi kullanılmaktadır. Buradaki konuları, alan olarak değerlendirmek mümkündür. Dijital oyunlara ilişkin tezlerin 34 farklı alanda yazıldığı görülmektedir. Alanların ayrımı, YÖK Tez Merkezi tarafından yapılmıştır. Radyo ve televizyon, Sayfa|529 halkla ilişkiler, reklamcılık ve gazetecilik alanlarının, iletişim bilimleri disiplininden ayrı tutulduğu görülmektedir. Türkiye'deki üniversitelerin akademik yapılanmalarına bakılarak, söz konusu 4 alanı, iletişim bilimlerine dahil etmek yanlış olmayacaktır. Bu durumda; iletişim bilimleri alanında dijital oyunlara ilişkin yayımlanmış tez sayısı 70 olacak ve iletişim bilimleri, dijital oyunlara ilişkin en çok tezin yazıldığı ikinci alan olacaktır.

TÜBİTAK Ulakbim Elektronik Kaynaklar Ulusal Akademik Lisansı veri tabanında "dijital oyun, video oyunu, bilgisayar oyunu, mobil oyun, konsol oyunu" anahtar kelimeleri ile arama yapıldığında, ilki 2006 yılında yayınlanmış 232 akademik makale ile karşılaşılmaktadır (EKUAL Keşif, 2020).

Demirbaş, dijital oyunlara ilişkin akademik yaklaşımlardaki tartışmalara alternatif bir bakış açısı getirdiği makalesinde; dijital oyunlara ilişkin Türkiye'deki akademik çalışmalar için, şu görüşü yapmaktadır:

"Yerel çalışmalarda, oyun çalışmalarının ana akım tezlerine benzer şekilde, benzer argümanlarla, var olan sorunları da devralarak yürütülen, ancak farklı olarak birbirine temas etmeyen, atomize bir görünüm göze çarpmaktadır" (Demirbaş, 2017: 354). 


\section{3. İLETİ̧̧İM BİLİMİNDE DİJİTAL OYUNLAR ÜZERİNE YAPILAN ÇALIŞMALARIN BETİMSEL ANALİí}

\subsection{Araştırmanın Sorunu}

Dijital oyunlar üzerine yapılan akademik çalışmalarda, disiplin, kuram ve yöntem bağlamında bir uzlaşı sağlanamamıştır. Dijital oyunların bilimsel araştırmalara konu olmaya başladığı erken dönemlerden itibaren, pek çok farklı disiplin tarafından farklı yöntemlerle incelenen oyunların, başka disiplinler aracıllı̆ıyla değil; "oyun çalışmaları" isminde başlı başına bir disiplin tarafından incelenmesi gerektiği de tartışımaktadır. Modern insan yaşamında gittikçe daha önemli bir hale gelen dijital oyunların daha iyi anlaşıması için, bilim içerisinde hiyerarşik bir düzene oturması, yöntem ve yaklaşımlarının belirlenmesi önem arz etmektedir. Dijital oyunları oynayan, onların ne olduğunu deneyimleyen insan sayısı giderek artsa da toplumun bir kesiminde hala olumsuz çağrışımlar uyandıran "çocuk oyunları" olarak yer edinmektedir. Dijital oyunların daha iyi anlaşıması, onun işlevselliğini daha da güçlendirecektir.

\subsection{Araştırmanın Amacı}

Bu araştırmanın amacı, Türkiye'de iletişim biliminde dijital oyunlara yönelik bilimsel çalışmaların betimsel bir analizinin yapılması, bulguların ve sonuçların literatüre katkı sağlamasıdır

\subsection{Araştırmanın Soruları}

Bu araştırma, şu sorulara yanıt aramaktadır:

1) Dijital oyunlara ilişkin akademik çalışmaların araştırma odaklarına aldıkları konular neler olmuştur?

2) Dijital oyunlara ilişkin akademik çalışmaların kuramsal yaklaşımları ve kavramsal çerçeveleri nelerdir?

3) Dijital oyunlara ilişkin akademik çalışmalarda kullanılan bilimsel yöntemler nelerdir?

4) Literatürdeki dijital oyunların incelenmesine yönelik anlatım bilimi

- ludoloji tartışması bağlamından bakıldığında, Türkiye'de dijital oyunların bilimsel incelenmesindeki yaklaşım nasıldır?

\subsection{Araştırmanın Önemi}

Alan yazındaki çalışmaların hangi konulara odaklandığının ortaya çıkarılması, dijital oyunların kültürel, ekonomik ve politik konumunun belirlenmesinde yardımcı olacaktır. Bilimsel araştırmalara konu olduğu ilk 
yıllardan itibaren önemi vurgulanan, üzerinde kesin bir anlaşma sağlanamamış "dijital oyunların hangi disiplin ya da disiplinlerce, kuramsal yaklaşımlarla ve hangi yöntemlerle araştırılması gerektiği" sorusuna yardımcı olabilecek bulgular ve sonuçlara ulaşılabilecektir. Dijital oyunlarla ilgili yapılacak akademik çalışmalarda, yeni araştırma konuları bulunmasına yardımcı olabilecektir. Literatürde sıklıkla yer bulmuş yaklaşım ya da yöntemlerin farkında olmak, yeni çalışmaların nereden başlayacağına dair kaynak oluşturabileceği gibi, tersi bir durum olarak, hiç denenmemiş yöntemleri de denemeye cesaret verebilir.

\subsection{Araştırmanın Yöntemi}

Bu çalışma, betimsel analiz yöntemini kullanmaktadır. İgit, betimsel analizi "genel tematik çerçeve oluşturma bir başka deyişle kategori oluşturma, tema ve alt temalar oluşturma aşamaları üzerinden genelden özele giden tümdengelim tekniği" olarak tanımlamaktadır (İgit, 2019: 95). Bu analizin öncesinde, oyun çalışmalarıyla ilgili literatüre başvurarak temel tanımlar ve yaklaşımlar incelenmiştir. Ardından, Şimşek ve Yıldırım'ın betimsel analizde önerdiği 4 aşama uygulanmıştır. Bu aşamalar; "betimsel analizin çerçevesini oluşturma, tematik çerçeveye göre verilerin işlenmesi, bulguların tanımlanması, bulguların yorumlanması" şeklindedir (Şimşek ve Şimşek, 2018).

İlk aşama olan çerçeve oluşturma için; bu araştırmacı tarafından veri toplama aracı olarak "21 başlıklı analiz tablosu" oluşturulmuştur. Tablodaki başlıklar oluşturulurken, bu araştırmanın sorularına yanıt aramaya yönelik bulgular çıkarma amacı gözetilmiştir.

Tabloyu oluşturan başlıklar: "Araştırmanın yılı, yazarı, yazarın ana bilim dalı, araştırmanın başlığı, türü (doktora ya da yüksek lisans), dili, araştırmanın oyun ya da oyuncuya odaklanması, odaklanılan konu, konu teması, konu temasının olumlu ya da olumsuz oluşu, araştırmanın amacı, araştırmanın kavramsal çerçevesini oluşturan başlıklar, araştırmanın kuramsal yaklaşımı, bu kuramın kategorisi (örneğin edebiyat kuramı ya da politik kuram), araştırmacının uygulama kısmında kullandığı yöntem, yöntem türü (nitel, nicel ya da karma), veri toplama aracı, araştırmanın örneklemi, oyunların anlatı ya da yapısal yönüne odaklanma, ulaşılan sonuçlar, sonucun olumlu ya da olumsuz durumu" olmak üzere 21 tanedir. Bu tabloya, bir de ele alınacak tezlerin kod numaraları eklenmiştir. Çalışma boyunca araştırma kapsamındaki tezlerden bahsedilirken, kod numaraları belirtilecektir. 
$\mathrm{Bu}$ ana tabloya ek olarak, ele alınan çalışmaların kavramsal çerçevelerini ve kuramsal yaklaşımlarına yön veren isimleri bir bütün içerisinde daha detaylı analiz edebilmek için; literatür taraması sonucunda geleneksel oyunu inceleyen Johan Huizinga ve Roger Caillois, ludoloji çalışmaları yapan Espen Aarseth, Jesper Juul, Lars Konzack, Markku Eskelinen, Gonzala Frasca ve oyunları anlatılar olarak inceleyen Brenda Laurel, Janet Murray, Michael Mateas'ın isimleri ile bir tablo yapılmıştır.

İkinci aşama olarak, araştırma kapsamındaki 21 tez okunmuş ve oluşturulan iki tablo içerisine veriler işlenmiştir. Üçüncü aşamada, tablo vasıtasıyla toplanmış nitel ve nicel veriler, bu araştırmanın sorularına yanıt bulma amacıyla analiz edilmiş ve bulgular tanımlanmıştır. Analiz esnasında tablodaki başlıkları dolduran veriler hem kendi içerisinde hem de diğer başlıklardaki verilerle ilişkisi içerisinde değerlendirilmiştir.

Dördüncü aşama olan bulguların yorumlanması; hem bulguları tanımlama sürecinde literatür ile ilişkilendirilerek, hem de araştırmanın sonuç, tartışma ve öneriler kısmında gerçekleştirilmiştir.

\subsection{Araştırmanın Örneklemi}

Yükseköğretim Kurulu Ulusal Tez Merkezi Veri Tabanında; çalışmasını "iletişim bilimleri" alanında kategorize eden araştırmacıların tezleri içinde, Sayfa | 532 "dijital oyunlar" ve "video oyunları" ifadelerini başlığında içeren 21 tez araştırmanın örneklemini oluşturmaktadır.

Araştırmanın örneklemi, olasılığa dayalı olmayan örnekleme tekniklerinden amaçsal örnekleme ile seçilmiştir.

\subsection{Araştırmanın Sınırlılıkları}

Bu araştırma, Türkiye'de dijjital oyunlar üzerine yapılan bilimsel çalışmalardan, yalnızca "Yükseköğretim Kurulu Ulusal Tez Merkezi Veri Tabanında" bulunan tezleri örneklemine almıştır. Yalnızca "Dijital Oyunlar", "Video Oyunları" anahtar kelimelerini başlığında içerenler örnekleme alınmış; "Bilgisayar Oyunları", "Konsol Oyunları", "Mobil Oyunlar" gibi anahtar kelimeler araştırma kapsamına dahil edilmemiştir.

\subsection{Bulgular}

Bu araştırmanın örneklemine alınan 21 Tez, Tablo 2'deki gibidir. Bulguların tanımlanması sürecinde, tezler kod numaraları ile temsil edilecektir.

\begin{tabular}{cccc} 
Kod & Yıl & Yazar & Başlık \\
\hline 1 & 2010 & Deniz Yenğin & Dijital Oyunlarda Şiddet Kavramı: Yeni Şiddet \\
\hline
\end{tabular}


22013 Sercan Şengün Six Degrees of Video Game Narrative:

A Classification for Narrative in Video Games

\begin{tabular}{|c|c|c|c|}
\hline 3 & 2014 & Özge Sayılgan & $\begin{array}{c}\text { Etkileşimli Drama Olarak Dijital Oyunlar ve "Etkileşimliliğin } \\
\text { İdeolojisi" Bağlamında Oyuncu Alımlama Pratikleri }\end{array}$ \\
\hline 4 & 2016 & $\begin{array}{l}\text { Mira Elif Demirhan } \\
\text { Sayın }\end{array}$ & $\begin{array}{c}\text { Dijital Oyunların Bilişsel Yeteneklere Etkileri: Faktör Referanslı } \\
\text { Bilişsel Test Kiti ile Oyuncu ve Oyuncu Olmayan Grupların } \\
\text { Karşılaştırılması }\end{array}$ \\
\hline \multirow{2}{*}{5} & \multirow{2}{*}{2017} & \multirow{2}{*}{ Efe Shipman } & Influential Aspects on Purchase Frequency \\
\hline & & & of Video Games Among Millennials In Turkey \\
\hline 6 & 2017 & Mert Erbil & $\begin{array}{c}\text { Localization Factors of Video Games and Impacts on Digital } \\
\text { Purchasing Behavior }\end{array}$ \\
\hline 7 & 2017 & Tülin Sepetci & $\begin{array}{c}\text { Dijital Oyunlar, Dijital Oyuncular: Karşı Hegemonya Pratikleri ve } \\
\text { Sosyal Etkileşim }\end{array}$ \\
\hline 8 & 2018 & Muhammed Raşit Gür & $\begin{array}{c}\text { Çok Oyunculu Dijital Oyunlarda Oyun Oynama Pratikleri: Moba ve } \\
\text { Mmorpg Oyunlar Üzerine Karşılaştırmalı Bir İnceleme }\end{array}$ \\
\hline 9 & 2018 & Nilüfer Zeynep Yavuz & $\begin{array}{c}\text { Challenging the Influence of Interactivity on Narrative Structures } \\
\text { in Digital Games. An Analysis of Adventure Genres }\end{array}$ \\
\hline \multirow{2}{*}{10} & \multirow{2}{*}{2018} & \multirow{2}{*}{ Vedat Yiğitoğlu } & Oyun Değer Dijital Oyunlar ve Kullanıcılar \\
\hline & & & Üzerine Bir İnceleme: To The Moon Örneği \\
\hline 11 & 2019 & Adnan Alican Sönmez & $\begin{array}{l}\text { A Taxonomy Proposal for Video Games with a Focus on } \\
\text { Visualization Modes }\end{array}$ \\
\hline 12 & 2019 & Aslı İgit & Dijital Oyunlar Aracılığıyla Empatik İletişim İnşası \\
\hline 13 & 2019 & $\begin{array}{l}\text { Damla Pınar } \\
\text { Kürkçüoğlu }\end{array}$ & Varlık Alanı Olarak Dijital Oyunlar ve Sanal Nesneler \\
\hline 14 & 2019 & Gökmen Kaya & $\begin{array}{c}\text { Re-Imagining "The East": Digital Games, Neo-Orientalism and } \\
\text { Representation } \\
\text { of the Other in Military Shooter Games }\end{array}$ \\
\hline 15 & 2019 & Mehmet Emir Yıldız & $\begin{array}{c}\text { Derin Oyun Olarak Futbol Video Oyunları: Trabzon'da Futbol Video } \\
\text { Oyun Kültürleri Üzerine Etnografik Bir Değerlendirme }\end{array}$ \\
\hline 16 & 2019 & Murat Sağlam & $\begin{array}{l}\text { Dijital Oyunların Öznel İyi Oluşa Etkisi: Y Kuşağına Yönelik Bir } \\
\text { Araştırma }\end{array}$ \\
\hline 17 & 2019 & $\begin{array}{l}\text { Simay Gizem } \\
\text { Çavuşoğlu }\end{array}$ & An Analysis Framework for Experiential Spaces in Video Games \\
\hline 18 & 2019 & Volkan Erol & Modlarla Açık Yapıta Dönüşen Video Oyunları ve Skyrim Örneği \\
\hline 19 & 2019 & Yusuf Taşkıran & Dijital Oyunlarda Oryantalist Söylem \\
\hline 20 & 2020 & Ayşegül Sürücü & Animal Cruelty in Video Games: An Ethical İnvestigation \\
\hline 21 & 2020 & Özgür Coşkun & $\begin{array}{c}\text { Dijital Oyunlarda Propaganda: "Call of Duty World War 2" } \\
\text { Oyununun İncelenmesi }\end{array}$ \\
\hline
\end{tabular}

Tablo 2: Araştırma Örneklemine Alınan Lisansüstü Tezler ve Verilen Kodlar

Çalışma birimine alınan 21 tez, iletişim bilimleri alanında; 9'u doktora ve 12 'si yüksek lisans tezi olarak yazılmıştır. Tezlerin yazıldığı dallar; iletişim bilimleri, radyo, televizyon ve sinema, pazarlama iletişimi, yeni medya, halkla ilişkiler ve tanıtım, gazetecilik, medya ve kültürel çalışmalar, basın ve yayın anabilim dalları ile oyun tasarımı programlarıdır. 
Tezlerin 13'ü Türkçe, 8'i İngilizce dilinde yazılmıştır. Doktora tezlerinin tamamı Türkçe yazılırken, 12 yüksek lisans tezinin 4'ü Türkçe, 8'i İngilizce yazılmıştır.

\subsubsection{Araştırma Kapsamındaki Tezlerin Odakları: "Oyun - Oyuncu, Konu ve Konu Teması, Olumlu - Olumsuz Odak"}

Ele alınan tezlerin başlığı, amacı, örneklemi ve sonucu incelendiğinde, araştırma kapsamındaki çalışmaların 10'unun oyuna, 9'unun oyuncuya, 2 'sinin hem oyun hem oyuncuya odaklandığı ortaya çıkmıştır. Bu sonuca dair veriler Tablo 3'teki gibidir.

\begin{tabular}{ccc} 
Odak / Tez Türü & Yüksek Lisans & Doktora \\
\hline Oyun Odaklı Tezler & 9 Adet & 1 Adet $(18)$ \\
\hline Oyuncu Odaklı Tezler & $(2,9,11,13,14,17,19,20,21)$ & 6 Adet \\
\hline Oyun ve Oyuncu Odaklı Tezler & 3 Adet $(5,6,8)$ & $(4,7,10,12,15,16)$ \\
\hline
\end{tabular}

Tablo 3: Oyun ya da Oyuncuya Odak ve Tez Türü İlişkisi (Parantez içindeki numaralar, bu araştırmada verilen tez kodlarını gösterir)

Tablo incelendiğinde, daha derinlemesine ve kapsamlı olan doktora tezlerinin dijital oyunların kendisini incelemekten ziyade, oyunlar ve oyuncunun ilişkisini incelediği görülmektedir. Daha derin ve kapsamlı çalışmaların, oyunların nasıl alımlandığı ile ilgilendiğini söylemek mümkündür. Bu noktada doktora tezlerinin, Garrelts'in önemine dikkat çektiği, oyun ve oyuncu ilişkisine odaklandığı görülmektedir (Garrelts, 2005).

Lankoski ve Björk, oyuna odaklanan tezlerin, oyuncu odaklı tezler için güçlü bir temel oluşturduğunu belirtmektedir (Lankoski ve Björk, 2015: 6, 7). Bu şekilde yaklaşımı 1 ve 3 kod numaralı tezlerde görmek mümkündür. 1 Kod numaralı doktora tezi önce içerik analizi ile oyunu incelemiş, daha sonra anket ile oyundaki şiddet unsurları ve oyuncunun etkileşimini sorgulamıştır. 3 Kod numaralı doktora tezi önce metin analizi ile oyunu incelemiş, daha sonra gözlem ve derinlemesine görüşme tekniği ile oyuncuların alımlamaları sorgulanmıştır.

Yüksek lisans tezlerinin çoğu yalnızca oyunun kendisine odaklanmış, Lankoski ve Björk'ün belirttiği gibi, oyuncuya dair varsayımlarda bulunmuş ya da onları arka planda tutmuştur.

Çalışmaların araştırma konuları, en genel anlamda dijital oyunlardır. Daha sonra, araştırma konularının "Oyunların içinde yer alan bir kavram", 
"Oyunların bir etkisi" ve "Oyunun yapısına dair" olmak üzere 3 kategoride toplandığını söylemek mümkündür. Bu kategoriler ve çalışmaların konuları tablo 4 'te verilmiştir.

\begin{tabular}{ccc} 
Ana Konu & Alt Konu: & $\begin{array}{c}\text { Tez } \\
\text { Kodu: }\end{array}$ \\
\hline & Alımlama & $1,3,10$ \\
& Bilişsel Yetenek & 4 \\
& Sosyal Etkileşim & 7 \\
Satın Alma & 5,6 \\
Oyun Etkisi & Oynama & 8 \\
& Motivasyonu & 16 \\
& Öznel İyi Oluş & 12 \\
& Empati & 15 \\
\hline Oyun & Oyun Kültürü & 2,9 \\
Yapısı & Anlatı Unsuru & 13,17 \\
& Öğeler / Uzam & 11 \\
& Görseller & 18 \\
& Mod Yazılımlar & 3 \\
\hline İçinde & Etkileşim & 1,20 \\
Yer Alan & Neo / Oryantalizm & 14,19 \\
Kavram & Propaganda & 21
\end{tabular}

Tablo 4: Ele Alınan Tezlerdeki Araştırma Konuları (1 ve 3 Kod numaralı tezler hem oyun hem de oyuncuya odaklandığı için ikişer konu içerir)

Araştırmaların konuları incelendiğinde, konuların kişi veya toplum yararına net bir yarar ya da zarar sağlaması açısından olumlu, olumsuz ve nötr olarak değerlendirilmesi mümkündür. Böyle bir yaklaşımla, çalışmaların 5 tanesinin olumsuz konulara (Şiddet, neo/oryantalizm, propaganda) odaklanmış olduğu görülmektedir. 5 Çalışma ise olumlu konulara odaklanmıştır. Bu konular; Bilişsel yetenek, sosyal etkileşim, öznel iyi oluş, empati, mod yazılımlardır. Mod yazılımların konu edildiği 18 kod numaralı çalışma, modlar sayesinde oyunların açık yapıtlara dönüştüğünü, bu sayede bireylerin kendi kültür, görüş ve iç dünyalarını ifade edebilecekleri bir mecra olduğunu konu edinmiş, bu sebepten ötürü bu çalışmada olumlu olarak değerlendirilmiştir (Erol, 2019). Ele alınan çalışmaların 11 tanesinin araştırma konusu, net bir şekilde olumlu ya da olumsuz değerlendirilememiş, nötr olarak değerlendirilmiştir. Bu konular: Anlatı unsurlarının, oyunların nasıl alımlandığının, satın almaya etken faktörlerin, oynama motivasyonlarının, oyun yapısının ve oyun kültürünün 
sorgulanması gibi konulardan oluşmaktadır. Oyunların etkisini konu edinen çalışmalar, çoğunlukla olumlu konuları ele almıştır. Oyunlara dair olumsuz yönleri konu edinen çalışmalar, oyunun kendisini odak noktasına almıştır. Olumsuz özellikleri barındıran oyunlardaki bu özelliklerin, oyuncular tarafından nasıl alımlandığı da önemlidir, bilimsel çalışmalara konu olmalıdır.

\subsubsection{Araştırma Kapsamındaki Tezlerin Kuramsal Yaklaşımları ve Kavramsal Çerçeveleri}

İncelenen araştırmaların 11 tanesi, kuramsal yaklaşımlarını açık bir şekilde belirtmiştir. Bu yaklaşımlar ve bu çalışmanın yazarı tarafından saptanmış kategorileri Tablo 5'teki gibidir.

\begin{tabular}{|c|c|}
\hline $\begin{array}{l}\text { Edebiyat } \\
\text { Kuramı }\end{array}$ & $\begin{array}{l}\text { Anlatım Bilimi: } \\
\text { Janet Murray (2) }\end{array}$ \\
\hline $\begin{array}{l}\text { Felsefe } \\
\text { Kuramı }\end{array}$ & $\begin{array}{c}\text { Post } \\
\text { Modernizm (10) }\end{array}$ \\
\hline $\begin{array}{c}\text { Antropoloji } \\
\text { Kuramı }\end{array}$ & $\begin{array}{l}\text { Horoz Dövüşü: Derin } \\
\text { Oyun: } \\
\text { Clifford Geertz (15) }\end{array}$ \\
\hline $\begin{array}{l}\text { Pazarlama } \\
\text { Kuramı }\end{array}$ & $\begin{array}{l}\text { Müşteri Değer } \\
\text { Teorisi (6) }\end{array}$ \\
\hline $\begin{array}{l}\text { Politik } \\
\text { Kuram }\end{array}$ & $\begin{array}{c}\text { Hegemonya, } \\
\text { Karşı Hegemonya (7) }\end{array}$ \\
\hline $\begin{array}{l}\text { Psikoloji } \\
\text { Kuramı }\end{array}$ & $\begin{array}{c}\text { Çok Boyutlu } \\
\text { Psikolojik } \\
\text { İyi Oluş: Carol Ryff } \\
\text { (16) }\end{array}$ \\
\hline $\begin{array}{l}\text { Sosyoloji } \\
\text { Kuramı }\end{array}$ & $\begin{array}{c}\text { Sembolik Etkileşim, } \\
\text { Kültürel Göstergeler } \\
\text { ve } \\
\text { Ekme: George } \\
\text { Gerbner (12) }\end{array}$ \\
\hline
\end{tabular}

Tablo 5: Tezlerde Açık Şekilde Belirtilen Kuramsal Yaklaşımlar ve Onların Kategorileri (Parantez içindeki numaralar tez kodunu gösterir)

Tablo 5 incelendiğinde, iletişim bilimi alanında dijital oyunlar üzerine çalışmalar yapan araştırmaların, farklı disiplinlerin kuramlarından yararlandığı görülmektedir. Açık bir şekilde ana kuramsal yaklaşımın 
belirten tezler içerisinde, iletişim biliminde sıklıkla çalışılan kuramların kullanılmadığı görülmektedir. Eksikliğinden bahsedilen kuramlar; çeşitli iletişim modelleri, kitle iletişim kuramları, kullanımlar ve doyumlar teorisi, ekonomi politik, kültür endüstrisi ve ağ toplumu kuramları, sıcak ve soğuk iletişim araçları, teknolojik belirleyicilik, yeni medya, sosyal medya, kültürel çalışmalar gibi iletişim biliminde farklı disiplinlerle ortak kullanılan kuramsal yaklaşımlardır (Güngör, 2020). Bu kuramların, çalışmalarda ana kuram olarak belirtilmediği, ancak kavramsal çerçeveler oluşturulurken değinildiği görülmüştür.

Dijital oyunları incelerken anlatım bilimi kuramlarına yer veren 4 çalışma bulunmaktadır. Bu çalışmalardan 3'ü, oyunlardaki anlatıları incelerken, biçim ve yapı özelliklerini inmal etmemekte, değerlendirmeye almaktadır. Yalnızca 9 kod numaralı tez, sadece anlatı özelliklerine odaklanarak; "macera oyunu senaryolarının nasıl oluşturulduğunu anlamak" ve "oyunların yapısında klasik anlatının izlerinin nasıl yer aldığını görmek, bu duruma interaktivitenin etkisini belirlemek" amaçlı çalışma gerçekleştirmiştir (Yavuz, 2018).

Boellstroff'un dijital oyunların Antropoloji disiplini aracılığıyla ve katılımcı gözlem metoduyla yaklaşılması önerisinin, 15 kod numaralı tezde karşılık bulduğu görülmektedir (Boellstorff, 2006: 30). Futbol video oyunların kültürünü betimlemeyi amaçlayan Yıldız, etnografi yöntemi içerisinde katılımlı gözlem ve yarı yapılandırılmış görüşmelerle veri toplayıp sonuca ulaşmıştır (Yıldız, 2019).

Dijital oyunların satışına, oyuncuların satın alma eğilimlerine odaklanan 5 (Shipman, 2017) ve 6 kod numaralı tezlerin pazarlama kuram ve kavramlarından yararlanıldığı, ekonomi politik gibi eleştirel kuramlar penceresinden bakılmadığı saptanmıştır. 6 Kod numaralı çalışma, iletişim biliminde önemli bir yer etmiş küreselleşme teorisinin yerelleştirme kavramını çalışma odaklarından birine koymuştur (Erbil, 2017).

İncelenen araştırmaların 15'i, çalışmalarına geleneksel oyun kavramı ile başlamıştır. Johan Huizinga'nın geleneksel oyun tanımı sıklıkla yazarların dijital oyun araştırmalarını temellendirdiği kuram olmuştur. Huizinga'nın sihirli çember kuramından da yararlanılmıştır. Roger Caillois'in oyun tanımı, özellikleri ve özellikle oyun sınıflandırması, yazarların başlangıç noktası olmuştur. Huizinga'nın oyunlara dair görüşleri 15 çalışmada yer bulurken, Caillois'in görüşlerine 12 çalışmada değinilmiştir. 
İncelenen araştırmaların 17'sinde, ludoloji disiplinin önemli temsilcileri kavramsal kısımda yer bulmuştur. Bu araştırmaların tamamında ludolojist Jesper Juul'un oyun tanımı ve özellikleri yer bulmuştur. Çalışmaların 13'ünde, Espen Aarseth'in hiper metin kavramı, dijital oyunların oyun çalışmaları disiplininde incelenmesi gerektiği şeklindeki görüşleri, tanım ve metodolojiye yönelik görüşler bulunmaktadır. 10 Çalışmada Gonzalo Frasca, 6 çalışmada Markku Eskelinen ve 4 çalışmada da Lars Konzack'ın dijital oyun çalışmalarına değinilmiştir.

Örnekleme alınan lisansüstü tezlerde, oyunların yalnız geleneksel bir disiplinin altında değil, başlı başına bir disiplin olarak incelenmesi gerektiğini savunan görüşlere önem verildiği görülmektedir. Dijital oyunları bir anlatı gibi inceleyen yaklaşımlara daha az yer verilmiştir. 21 çalışmanın 9 tanesi, oyunları geleneksel anlatılarla ilişkilendiren Janet Murray'ın görüşlerine yer vermiştir. 4'er çalışmada, oyunların etkileşimli dramalar olarak nitelendirildiği, Aristotelesçi yaklaşımlarda bulunan Brenda Laurel ve Michael Mateas yer almıştır.

İncelenen araştırmaların 3 tanesi, literatürdeki yoğun eğilimden farklı olarak, çalışmalarında literatürdeki "geleneksel oyun", "ludoloji" ve "oyunanlatı ilişkisi" kuram ve kavramlarına hiç değinmemiştir. Bu çalışmalar içerisindeki 6 kod numaralı tez, "oyunları satın alma davranışına etki eden unsurları saptama" amacını gütmüş ve pazarlama kuram, kavramlarına yer vermiştir (Erbil, 2017). 11 kod numaralı "Görsel odaklı taksonomi oluşturma" amacı taşıyan tez, literatürdeki dijital oyun teknolojilerine değinmiştir (Sönmez, 2019). 19 Kod numaralı tez, "dijital oyunlarda oryantalist söylem" ana temasında ve ideolojik kavram ve kuramlar perspektifinden araştırma gerçekleştirmiştir. Araştırmasının uygulamasını dijital oyunlar üzerinde yapmasına rağmen oyunlara dair bir kavramsal çerçeve oluşturmamıştır (Taşkıran, 2019). Geleneksel oyun kavramına hiç değinmeyen çalışmaların, Nieborg ve Hermes'in, dijital oyunlar, geleneksel oyundan ayrı tutularak incelenebilir görüşüyle uyuştuğu saptanmıştır (Nieborg ve Hermes, 2008).

Çalışmalarındaki ana kuramsal yaklaşımı net bir şekilde belirtmeyen tezlerin, kavramsal çerçeveleri incelenmiştir. Bu inceleme sonucunda çalışmaların dijital oyunlar üzerine yaptıkları araştırmalarında ideolojiler bağlamında; hegemonya, karşı hegemonya, organik aydın, aydın, oryantalizm, neo-oryantalizm, militarizm, oksidentalizm zenofobi ve islamofobi, emperyalizm, propaganda kavramlarına ve Marx, Engels, 
Althusser, Gramsci, Ernesto Laclau, Chantal Mouffe gibi kişilerin görüşlerine yer verdikleri görülmüştür.

Çalışmalarında psikoloji, sosyoloji ve sosyal psikoloji disiplinlerinden faydalananların; biliş, zekâ, şiddet, yeni şiddet, psikometri, zekâ, öznel iyi oluş, haz ve acı, uyum, akış, uyuşmazlık, empati, sembolik etkileşim, toplum, cemaat kavram ve kuramlarına yer verdiği görülmüştür. Felsefi kavram ve kuramlardan yararlananlar; varlık, uzay ve mekân, zaman, ütopya, distopya, etik başlıklarına ve Aristotales, Kant, Foucault'un düşüncelerine yer vermişlerdir.

Çalışmalarda iletişim bilimiyle iliş̧ili; teknolojik belirlenimcilik, yeni iletişim, medya, yeni medya, sosyal medya, eleştirel kuram, ağ toplumu, bilgi ve bilişim toplumu, kültür endüstrisi, kültürel göstergeler ve ekme kuramı, empatik iletişim, bilgi teknolojileri, kültürel çalışmalar kavram ve kuramları ile Theodor Adorno, Max Horkheimer, Stuart Hall, Marshall Mcluhan'ın görüşleri yer bulmuştur.

Çalışmalarda ayrıca, simulasyon, hiper gerçeklik, sanal dünya, siberkültür, sibermetin, sanal nesne, sanal kültürler kavramlarına değinilmiştir.

\subsubsection{Araştırma Kapsamındaki Tezlerin Bilimsel Yöntemleri}

Araştırma kapsamındaki 21 tezin 13'ü nitel araştırma, 4'ü nicel araştırma, 4'ü karma araştırma yöntemini kullanmıştır. Tüm çalışmalar içerisinde 7 anket, 4'er derinlemesine görüşme ve göstergebilim, 3'er içerik analizi, araştırmacının kendi geliştirdiği metot, başka araştırmacının geliştirdiği metot ve 1'er tane de test, gözlem, söylem analizi, etnografi yöntemi kullanılmıştır.

Sadece nicel araştırma yöntemini kullananların tamamının araştırmalarında "oyuncu" odaklı oldukları ve veri toplama yöntemi olarak anket kullandıkları görülmüştür. Nicel araştırma yöntemini kullanarak oyunun kendisini inceleyen bir çalışma bulunmamaktadır.

Çalışmalarında "oyunun kendisi" odaklı olan araştırmaların tamamının, nitel araştırma yöntemlerini kullandıkları, bunların yalnızca bir tanesinin karma araştırma yöntemini kullandığı görülmüştür. Nitel araştırma yapan oyun odaklı çalışmalarda en fazla göstergebilim yönteminin kullanıldığı tespit edilmiştir.

Bu araştırmanın ikinci bölümünde yer verilen, literatürdeki görüş ve yöntemler ile 21 tezin yöntemi arasındaki ilişki incelendiğinde yöntem 
bakımından benzerlik gösteren çalışmalar bulunmaktadır. Lankoski ve Björk'ün (Lankoski ve Björk, 2015), oyunları inceleyen nitel araştırmaların "yapı, zaman ve bilgi sistemi" bağlamında incelemeler yaptığı görüşü, 21 tez içerisinde karşılık bulmaktadır. Landers ve Bauer'in, oyunlar nicel araştırmalarla; testlerin ve istatistiksel yöntemlerin kullanılmasıyla incelenmelidir şeklindeki görüşü (Landers ve Bauer, 2015: 151, 152), 4 kod numaralı tezde karşılık bulmaktadır. Dijital oyunların bilişsel yeteneklere etkilerini inceleyen çalışma, faktör referanslı bilişsel test kitini ve anketi kullanarak oyuncu ve oyuncu olmayan grupları karşılaştırmıştır (Demirhan Sayın, 2016). Lieberoth ve Roepstroff hem oyun hem de oyuncuya odaklanarak, nitel ve nicel araştırmaların birlikte yapılmasının, güçlü sonuçlar vereceğini savunmaktadır (Lieberoth ve Roepstorff, 2015). Bu yöntem, 1 kod numaralı tezde bulunmaktadır. Yengin, dijital oyunlarda şiddet kavramını incelerken hem oyun hem de oyuncuya odaklanmıştır. Oyunlardaki şiddet unsurlarını içerik analizi ile sınıflandırır, daha sonra bu unsurların nasıl alımlandığını tespit etmek için anket yöntemini uygular (Yengin, 2010). Nicel araştırmalar yaparak sistematik verilere ulaşan 1, 4, $5,6,10,16$ ve 21 kod numaralı çalışmalar, Lieberoth ve diğerlerinin "oyunlar nicel yöntemlerle incelenmelidir" şeklindeki görüşleriyle uyum sağlamaktadır (Lieberoth ve Roepstorff, 2015).

Aarseth'in görüşlerine sıklıkla yer verilmekle birlikte, 3 katmanlı analiz yönteminin kullanılmadığı görülmektedir. Konzack'ın oyuna ve onun incelenmesine dair görüşlerine değinilse de 7 katmanlı oyun analiz yöntemi çalışmalarda kendine yer bulmamıştır. Nicel araştırma yöntemleri öneren Marzczak ve Schott'un görsel ve işitsel içeriklerin nicel analizine dayalı yöntem, Wallner ve Kriglstein'in oynanış verilerini görselleştirme yöntemi ve psikofizyolojiyi oyun araştırmalarında kullanma yöntemi kullanılmamıştır. Nicel araştırma yapan yazarlar, geleneksel yöntem ve veri toplama tekniklerini tercih etmiştir (Konzack, 2002; Aarseth, 2003; Marczak ve Schott, 2015; Wallner ve Kriglstein, 2015; Lankoski ve Björk, 2015).

Araştırma kapsamındaki tezlerin yazarlarının çoğunluğunun, ele aldıkları oyunları oynayarak ve oyun hakkındaki elektronik kaynakları, diğer oyuncuların görüşlerini inceledikleri saptanmıştır. Bu da Aarseth'in önerdiği güçlü yöntem ile örtüşmektedir (Aarseth, 2003).

21 tez içerisinde, dijital oyunların akademik incelemelerinde kullanılmak üzere yeni bilimsel bir metot geliştirmeye çalışan; tamamı yüksek lisans tezi 4 çalışma bulunmaktadır. Şengün, "video oyunlarındaki 
anlatı kullanımlarını sınıflandırma amaçlı "6 dereceli referans sistemi" oluşturmuştur. Video oyunlarının anlatı ve söylemleri içerisinde etkileşim ve özerkliğin yerini sorgulamaktadır. Oyunların anlatı özelliklerini ön planda tutmasına rağmen, oyunların biçimsel özelliklerini göz ardı etmemiş, sınıflandırmasına dahil etmiştir. Sınıflandırma metodu, oyunlardaki anlatı ve yapısal özellikleri bir arada inceleyerek, anlatı derecelerini ölçmektedir (Şengün, 2013). Çavuşoğlu, video oyunlarının deneysel alanlarını analiz etmeye yarayan bir analiz çerçevesi oluşturmuştur. Video alanlarını; temsil, stil, navigasyon ve etkileşim şeklinde 4 katmanda kategorize etmiştir (Çavuşoğlu, 2019). Sönmez, dijital oyunlarda kullanılan bakış ve kamera açılarına dayalı bir taksonomi yöntemi geliştirmiş ve uygulamıştır (Sönmez, 2019). Kürkçüoğlu, felsefi kuramsal bakış açısına sahiptir; dijital oyunun nesnesini ve varlık alanını konu edinmekte ve dijital oyunlarda "nesne üzerine düşünmeyi kolaylaştırma amaçlı bir yöntem oluşturma" çabasındadır (Kürkçüoğlu, 2019).

\subsubsection{Araştırma Kapsamındaki Tezlerin Anlatım Bilimi - Ludoloji Yaklaşımı}

Çalışma kapsamına alınan 21 tezin 10 tanesi literatürdeki anlatım bilimi ve ludoloji arasındaki fikir ayrılıklarına hiç değinmemiştir. Tezler içerisinde, söz konusu tartışmaya yer veren ancak bu konuda kendi görüşünü bildirmeyen 6 çalışma bulunmaktadır. 3 Yazar, oyunların incelenmesinde bütüncül yaklaşım ve yöntemlerin kullanılması gerektiğini belirtmiştir.

Ele alınan 21 tezin amacı, odaklandığı konu, kullandığı yöntem ve örneklemi incelenerek, araştırmaların oyunların hangi yönüne odaklandığı saptanmıştır. 10 Araştırma, oyunların yalnızca yapısal yönlerini araştırmaktadır. 8 Araştırma, dijital oyunların hem anlatı hem de yapısal özelliklerine odaklanmaktadır. 3 Araştırma ise dijital oyunların içerdiği anlatı yönlerini incelemektedir.

Oyunlardaki anlatı yönünü inceleyen çalışmalardan bir tanesi, dijital oyun anlatımlarının 6 derecelik bir sınıflandırmasını yapan ve bir yöntem oluşturan Şengün'ün 2 kod numaralı tezi, oyunların anlatı özelliklerine değinirken, yalnızca anlatılardan ibaret olmadığını ispatlamaktadır. Oluşturduğu sınıflandırmayla; hiç anlatı içermeyen, yalnızca kahraman ya da kötü karakter gibi mecazi anlatılar içeren, yazılı metin ya da ara sahne gibi oyun dışı anlatılar içerenler, oyuncuların kendi anlatılarını oluşturmaya imkân sağlayan şeklinde kategoriler oluşturmuştur. Örneklemine aldığı çok 
satan oyunlara uygulamış ve yıllara göre anlatı kullanımlarını ortaya çıkarmıştır. Hiç anlatı içermeyen ya da yalnızca mecazi anlatılar içeren dijital oyunların satış rakamlarının yüksek olması, dijital oyunların yalnızca anlatılar olarak değerlendirilemeyeceğini, oyunların yapısal özelliklerinin göz ardı edilemeyeceğini göstermektedir (Şengün, 2013).

Anlatı özelliklerinin yoğun olduğu macera oyunlarının senaryo yapısını ve geleneksel anlatıların dijital oyunlarda varlığını, etkileşimin de varlığı altında sorgulayan 9 kod numaralı tez, dijital oyunlarda geleneksel anlatılarının izlerinin bulunduğu sonucuna ulaşmıştır. Ancak, klasik anlatılardan farklı olarak dijital oyunlardaki anlatılar oyunların doğrusal bir çizgide değil, karmaşık örgüde ilerlemesini sağlamakta, böylece yapay bir etkileşim hissi doğmaktadır (Yavuz, 2018).

\subsubsection{Araştırma Kapsamındaki Tezlerin Sonuçları}

Ele alınan 21 bilimsel çalışmanın sonuçları, bu araştırmanın ilk sorusu olan, dijital oyunların hangi konulara odaklandığı sorusuna cevap veren bulgulardır ve dijital oyunların insan yaşamındaki konumunu göstermesi açısından önemlidir. Araştırma kapsamındaki 1, 14, 19, 20 ve 21 kod numaralı tezler olumsuz değerlendirilebilecek şiddet, neo-oryantalizm, propaganda gibi konu temalarını araştırmaya odaklanıp, sonuçlarında: Dijital oyunların, hayvana yönelik şiddetin de dahil olduğu çeşitli şiddet öğeleri içerdiği, bu durumun özellikle çocuklarda duyarsızlaşmaya yol açtığı (Yengin, 2010; Sürücü, 2020), ilgi çekici yapısal, görsel ve işitsel özelliklerinin altında çeşitli propagandalar, negatif ve yoğun şekilde oryantalist söylemler içerdiği sonuçlarına vardıkları saptanmıştır (Kaya, 2019; Taşkıran, 2019; Coşkun, 2020).

Araştırma kapsamındaki 4, 7, 12, 16 ve 18 kod numaralı tezler; oyunların oyuncular üzerinde bilişsel yetenek, sosyal etkileşim, öznel iyi oluş, empati ve kendini ifade etme konuları bağlamında olumlu etkileri olduğunu araştırmaya odaklanmışlar ve sonuç olarak; dijital oyunların bireylerde bazı bilişsel yeteneklere pozitif etkiler yaptığı (Demirhan Sayın, 2016), çok oyunculu oyun oynayanların sosyal aktörler olduğu ve sosyalleşerek kendilerini ifade ettikleri (Sepetçi, 2017), "mod" ismi verilen yazılımlarla, oyuncuların oyunları kendilerini ifade edebilecekleri bir mecraya dönüştürdükleri (Erol, 2019), dijital oyunların empati duygusunu güçlendirdiği (İgit, 2019) ve oyun oynamanın, bireylerin iyi oluşlarına olumlu etki ettiği sonuçları saptanmıştır (Sağlam, 2019). 
Odaklandıkları konular bakımından nötr sayılabilecek 11 tezin 4 tanesi, başlangıçta nötr sorular sorup, sonuçlarında ağırlıklı olarak olumlu değerlendirilebilecek ifadeler kullanmışlardır. Etkileşimli drama olarak gördüğü dijital oyunların nasıl alımlandıklarını sorgulayan 3 kod numaralı tez, oyuncuların pasif tüketiciler değil, aktif özneler olduğu sonucuna ulaşmıştır (Sayılgan, 2014). Bu noktada Sayılgan'ın sonucu, Garrelts'in; oyuncunun karmaşık medya metinlerini çözebildiği fikriyle örtüşmektedir. Oyunları postmodernizm perspektifinden değerlendirip oyun özelinde kullanıc görüşlerini sorgulayan 10 kod numaralı tez, oyuncuların oyunu mutluluk ve tatmin için oynadıkları sonucuna ulaşmıştır (Yiğitoğlu, 2018). İki farklı oyun türünü ele alıp, bu türlerin oyuncularının oyun oynama motivasyonlarını sorgulayan 8 kod numaralı tez, oyuncuların psikolojik rahatlama ve sosyalleşme gibi sebeplerle oyun oynadığı sonucuna varmıştır (Gür, 2018). Futbol video oyun kültürlerinin nasıl olduğunu sorgulayan 15 kod numaralı tez, oyun kültürünün yerel değerlerin bir ifadesi olduğu, oyunların bireylerin kimliklerini ifade etmede aktif rol üstlendiği ve toplumsallaşma sağladığı şeklinde sonuçlara ulaşmıştır (Yıldız, 2019).

\section{SONUÇLAR, TARTIŞMALAR VE ÖNERİLER}

$\mathrm{Bu}$ araştırma öncelikle geleneksel ve dijital oyun kavramını, tarihçesini incelemiş, ardından literatürde dijital oyunların bilimsel olarak incelenmesine yönelik disiplin, kavramsal çerçeve, kuramlar ve yöntemlere dair görüşlere değinmiştir. Böylece dijital oyunların akademik çalışmalarda incelenme şekilleri ve eğilimleri hakkında bilgi sahibi olunmuştur. Daha sonra araştırma kapsamına alınan 21 tez, veri toplama aracı olarak oluşturulan " 21 başlıklı analiz tablosu" ile incelenmiş, betimsel analiz yöntemi ile analiz edilmiştir. Çalışma sonucunda, bu araştırmanın tüm sorularına yanıt bulunmuştur. Araştırma bulgularının yorumları, ulaşılan sonuçlar, tartışmalar ve ilgili öneriler, bu araştırmanın sorularının veriliş sırasıyla yazılacaktır.

Dijital oyunları inceleyen bilimsel çalışmaların araştırma odaklarına aldıkları konular en genel olarak üç noktada toplanmaktadır. Bunlar oyunların yapısı, oyunların etkisi ve oyunların içinde yer alan kavramlardır. Odaklanılan konular iletişim biliminin kapsamı içerisinde, geniş bir yelpazede yayılmaktadır.

Çalışmaların neredeyse eşit miktarda oyun ve oyuncuya odaklandığı görülmektedir. Bu çalışmanın kavramsal çerçevesini oluşturan literatürde; oyun odaklı çalışmaların temel araştırmalar olduğu, dijital oyunları daha iyi 
anlamak için oyuncuya, daha da iyi anlamak için hem oyun hem de oyuncuya yönelik çalışmalar yapılması gerektiği hususunda ortak bir görüşün varlığından söz etmek mümkündür. Bu bilginin ışığında yorumlandığında; ele alınan tezlerin az bir farkla daha çok oyuncuya odaklanması umut verici olsa da yalnızca 2 tezin hem oyun hem de oyuncuya odaklanması, bu şekildeki karma çalışmalara daha fazla ihtiyaç duyulduğunu göstermektedir. Araştırma kapsamında, oyuna odaklanan çalışmaların daha çok yüksek lisans tezleri olması, oyun odaklı çalışmaların başlangıç seviyesindeki araştırmalar olduğu görüşünü geçerli kılmaktadır. Toplumun azımsanmayacak bir kısmının hayatının önemli parçası haline gelen dijital oyunları anlamak ve etkilerini kontrol altında tutmak adına oyunlar incelenmeli ancak içerdiklerinin ve etkilerinin oyuncularda nasıl alımlandığı daha çok incelenmelidir. Bu sebeple oyuncuya odaklanan çalışmalara ağırlık verilmeli ve oyunların nasıl etkiler yarattığı daha iyi anlaşılmalıdır.

Araştırma kapsamındaki bilimsel çalışmaların odaklandıkları konulara bakarak, dijital oyunların insan hayatında olumlu ve olumsuz özellikleriyle birlikte var olduğu görülmektedir. Araştırma sonuçlarında, dijital oyunların olumlu özellik ya da etkilerinin olduğunu belirten 9 çalışma, oyunların insan ve toplum yararına işlevsel olarak kullanılabileceğinin bir göstergesidir. Dijital oyunların olumsuz özellik ve etkilerinin önlenmesi ve etkilerinin azaltılması için, toplumda "oyun okur yazarlığı" bilincinin oluşturulması, etkin bir çözüm oluşturacaktır. Oyunların etkilerini inceleyen çalışmalar, nötr ya da olumlu değerlendirilebilecek etkilere odaklanmıştır. Etkilerin yalnızca olumlu özellikler bağlamında araştırılmaması, olumsuz özellikler taşıyan oyunların etkilerinin de araştırılması önem arz etmektedir. Bu araştırmanın kapsamında oyunların olumsuz özelliklerini inceleyen çalışmalardan yalnızca "Dijital oyunlarda şiddet kavramı: Yeni şiddet" isimli çalışma (Yengin, 2010), hem oyun içerisindeki olumsuz ögeye hem de bu ögenin nasıl alımlandığına odaklanmıştır.

Dijital oyunların yeni medya düzeni içerisindeki konumuna odaklanmış çalışmaların eksikliği hissedilmektedir. Hem bireysel hem de kitle iletişim aracı olarak dijital oyunların kendisi medya ürünü olmakla birlikte, yeni medyada farklı alanlar da yaratmaktadırlar. Oyun yayıncılığının önemli boyutlara geldiği görülmektedir. Dijital oyunların ekosistemi içerisinde oyun yayıncılığının yeni medya ile ilişkilendirildiği çalışmaların artırıması gerekmektedir. 
Çalışmaların büyük bir çoğunluğu, dijital oyunları anlamak için ilk önce geleneksel oyun kavramını araştırmış, bunu yaparken de Huizinga'nın sihirli çember kuramı ve oyun tanımlarından sıklıkla yararlanmışlardır. Bu noktada, Huizinga'nın araştırmaların çoğunda temel oluşturduğunu söylemek mümkündür. Geleneksel oyunun sınıflandırmasında, Caillois'in oyun sınıflandırması kullanılmıştır. Dijital oyunları incelerken geleneksel oyun kavramına hiç değinmeyen çalışmalar bulunmaktadır. Nieborg ve Hermes (2008) bu durumu olağan karşılamaktadır. Araştırmanın odaklandığı konuya bağlı olarak, geleneksel oyun kavramını ve onun özelliklerini kavramsal çerçeve içerisinde tutmak ya da tutmamak seçenek olarak kalmalı, bir zorunluluk olmamalıdır.

Literatürdeki "dijital oyunlar farklı disiplinlerden, yöntemlerden yararlanmalıdır" görüşü ile paralel olarak, Türkiye'deki çalışmaların da tek ya da dar bir bakış açısıyla yapılmadığı saptanmıştır. İletişim bilimi disiplinine ait sayılabilecek geleneksel kuramların tercih edilmediği, ancak iletişim bilimine dair kavramların, araştırmaların kavramsal çerçevelerine eklendiği görülmektedir. Bu durumu, araştırmacıların dijital oyunu medya ürünü ya da kitle iletişim aracı olarak görmekten ziyade, başlı başına "oyun" olarak değerlendirmeleri şeklinde açıklamak mümkündür. Çalışmaların çoğunluğunda kavramsal çerçeveler oluşturulurken, ludoloji disiplinine yönelik bir eğilimin varlığı saptanmaktadır. Araştırma kapsamındaki tezlerde ludoloji alanında önemli isimlerin görüşleri sıklıkla yer bulmuştur. Edebiyat kuramı ve anlatım bilimine ait görüşler, daha az yer bulmaktadır.

Nieborg ve Hermes'in (2008), kültürel çalışmaları eleştirdiği yön; ekonomi politik bakış açısı eksikliğinin, bu araştırma kapsamındaki çalışmalarda da eksik olduğunu söylemek mümkündür. Oyuncuların satın alma sıklığını etkileyen faktörler ve oyuncuların satın alma motivasyonları araştırılmıştır, ancak büyük bir kültür endüstrisi olan dijital oyun sektörünün eleştirel ekonomi politik bakış ile incelenmediği görülmektedir. Bu eksikliği kapatmak adına dijital oyunların eleştirel ekonomi politik bakış açısıyla incelenmesi gerekmektedir.

Dijital oyunların konu çeşitliliği insan aklının hayal gücüyle sınırlıdır. Yapımlarında ve oynanışlarında kullanılan teknoloji ve tekniklerse her geçen gün gelişmekte ve daha karmaşık bir yapıya bürünmektedir. Böylesine büyük bir fenomenin içerdiklerinin bir sınırı yokken, onu inceleyecek disiplinlerin ve kuramsal perspektiflerin sınırlanması doğru değildir. 
Dijital oyunlar, iletişim biliminde daha çok nitel araştırmalarla incelenmektedir. En çok kullanılan nitel araştırma yönteminin göstergebilim ve derinlemesine görüşme olduğu görülmüştür. Nicel araştırmaların çoğunlukla anket yöntemini kullandığı görülmektedir. Araştırma kapsamına alınan çalışmaların oyunlara yaklaşım bakımından ludoloji disiplinine yakınlığı, yöntem bağlamında devam etmemiştir. Ludoloji disiplini içerisinde kullanılan ve önerilen yöntemlerin çoğu bizzat kullanılmamıştır, sadece nitel ya da nicel olması yönünden bazı benzerlikler bulunmaktadır.

Yeni bir yöntem deneyen çalışmaların tamamı yüksek lisans çalışmalarıdır ve bunlar, genel olarak dijital oyunları analiz etmeye yönelik değil, daha özel konularda analiz etmeye yöneliktir. Literatüre farklı bakış açılarından yeni yöntemler katmak adına, derinlemesine bilimsel araştırmalar olan doktora tezleriyle de metot geliştirme çalışmaları yapılmalıdır.

Araştırma kapsamındaki bilimsel çalışmalarda, literatürde süregelen disiplin tartışmaları önemli bir yer bulmaması, görüş bildiren az sayıdaki yazarın bütüncül bir yaklaşım önermesi; Türkiye'de dijital oyunların akademik incelenmesi konusunda iletişim biliminde disiplin bağlamında bir sorun olmadığını göstermektedir. Dijital oyunların neredeyse sınırsız çeşitlilikteki içerikleri ve çok sayıda olumlu işlev, olumsuz etkileri sebebiyle çok farklı disiplinlerce incelenmesi olağandır. Farklı yaklaşımlar dijital oyunları anlamada daha zengin perspektifler sunmaktadır. Bununla birlikte Türkiye'de dijital oyunlara dair bilimsel bir bütünlük sağlamak adına, işin daha çok teknik kısmına odaklanan üniversite bölümlerinin, oyun üretiminin yanı sıra oyunların incelenmesine odaklanması ve bu konuda yol haritaları oluşturması önem arz etmektedir.

Dijital oyunların içerisinde anlatıların da yer alabildiği, hatta bazı oyunlarda anlatı unsurunun çok baskın olduğu bir gerçektir. Ele alınan araştırmalar, bu gerçek içerisindeki iki tarafa da odaklanmıştır ancak genel eğilim, oyunların biçimsel ve yapısal özelliklerine odaklanmak olmuştur. Oyunların salt anlatı özelliklerine değinen yalnız 3 çalışma bulunmaktadır.

Literatürde oyunların bilimsel incelenmelerine dair görüşlerin; dijital oyunları tek ya da dar bir alana indirgeyerek onun bütününü gözden kaçırma kaygısı taşıdığı görülmektedir. Türkiye'de ise oyunların anlatı özelliklerine odaklanan çalışmaların, oyunların yapısal özelliklerini göz ardı etmediği görülmektedir. Oyundaki anlatılara odaklanan, diğer yandan 
oyunu bir film ya da romandan ayıran özellikleri de ihmal etmeyen çalışmalara ağırlık verilmelidir.

Özetle araştırma kapsamındaki lisansüstü tezler; oyunların yapısı, oyunların etkisi ve oyunların içinde yer alan kavramları konu edinmekte, oyun ve oyuncuya neredeyse eşit miktarda odaklanmakta ve oyunları olumlu ve olumsuz özellikleriyle birlikte ele almaktadır. Dijital oyunlara yaklaşımda çeşitli disiplinlerin kuramları perspektifinden bakılmakla birlikte; çalışmaların çoğunlukla Huizinga'nın geleneksel oyun tanım ve kuramlarıyla temellendirildiği, ludoloji disiplininin önemli isimleri ile kavramsal çerçevelerin oluşturulduğu görülmektedir. Çalışmaların en fazla nitel olarak gerçekleştirildiği, göstergebilim ve derinlemesine görüşme tekniklerinin kullanıldığı saptanmıştır. Literatürde süregelen, dijital oyunların hangi disiplin ile inceleneceği yönündeki fikir uyuşmazlığı, Türkiye'deki çalışmalarda karşılık bulmamaktadır.

Dijital oyunları incelerken odaklanılan konuya uygun bilimsel disiplini, kuramsal yaklaşımları, yöntemleri seçme konusunda bir sınırlama içerisine girilmemesi gerekmektedir.

\section{KAYNAKÇA}

Aarseth, E. (2001). Computer Game Studies, Year One. Game Studies $1(1), 1-1$.

Aarseth, E. (2003). Playing Research: Methodological Approaches to Game Analysis. Artnodes. doi:10.7238/a.v0i7.763

Akbulut, H. (2009). Gelenekselden Dijitale, Mekandan Uzama Oyun Kültürü. Dijital Oyun Rehberi: Oyun Tasarımı, Türler ve Oyuncu. içinde İstanbul: Kalkedon.

Arjoranta, J. (2014). Game Definitions: A Wittgensteinian Approach. Game Studies 14(1), 1-1.

Arnold, A. (1995). Çocuğunuz ve Oyun. İstanbul: Denge Yayınları.

Bayraktutan Sütçü, G. (2009). Dijital Oyun Çalışmalarında Yöntem: Genel Bir Bakış. (Düz.). M. Binark, G. Bayraktutan Sütçü \& I. Fidaner içinde, Dijital Oyun Rehberi: Oyun Tasarımı, Türler ve Oyuncu. İstanbul Kalkedon Yayınları.

Binark, M., \& Bayraktutan-Sütçü, G. (2008). Kültür Endüstrisi Ürünü Olarak Dijital Oyun. İstanbul: Kalkedon.

Boellstorff, T. (2006). A Ludicrous Discipline? Ethnography and Game Studies. Games and Culture 1(1), 29-33. 
Brookey, R. A. (2010). Hollywood Gamers: Digital Convergence in the Film and Video Game Industries. Bloomington: Indiana University Press.

Bryce, J., \& Rutter, J. (2006). An Introduction to Understanding Digital Games. (Düz.). J. Rutter \& J. Bryce içinde Understanding Digital Games. London: SAGE Publications.

Caillois, R. (2006). The Definition of Play, The Classification of Games. (Düz.). K. Salen \& E. Zimmerman içinde The Game Design Reader: A Rules of Play Anthology. London: The MIT Press.

Coşkun, Ö. (2020). Dijital Oyunlarda Propaganda: "Call Of Duty World War 2" Oyununun İncelenmesi. (Yayımlanmış Yüksek Lisans Tezi). İstanbul Aydın Üniversitesi, Lisansüstü Eğitim Enstitüsü.

Çavuşoğlu, S. G. (2019). An Analysis Framework for Experiential Spaces in Video Games. (Yayımlanmış Yüksek Lisans Tezi). Bahçeşehir Üniversitesi, Sosyal Bilimler Enstitüsü.

Demirhan Sayın, M. (2016). Dijital Oyunların Bilişsel Yeteneklere Etkileri: Faktör Referanslı Bilişsel Test Kiti İle Oyuncu ve Oyuncu Olmayan Grupların Karşılaştırılması. (Yayımlanmış Doktora Tezi). Marmara Üniversitesi, Sosyal Bilimler Enstitüsü.

Dutta, P. (2020, 11 14). The 20 Best Cloud Gaming Services Available in 2020. Erişim Adresi: ubuntupit.com: https://www.ubuntupit.com/best-cloud-gaming-services-available/ Erişim Tarihi: 16.12.2020.

Entertainment Software Association. (2020). Essential Facts About Video Game Industry. Entertainment Software Association.

Erbil, M. (2017). Video Game Localization Factors and Impacts on Digital Purchasing Behavior. (Master's Thesis). YÖK Ulusal Tez Merkezi. 456710.

Erol, V. (2019). Modlarla Açık Yapıta Dönüşen Video Oyunları ve Skyrim Örneği. (Doktora Tezi). Erişim Adresi: http://nek. istanbul.edu.tr:4444/ekos/TEZ/ET001255.pdf.

Eskelinen, M. (2001). The Gaming Situation. Game Studies 1(1), 1-1.

Frasca, G. (1999). Ludology Meets Narratology: Similitude and Differences Between (Video) Games and Narrative. Erişim Adresi: www.ludology.org: https://ludology.typepad.com/weblog/articles/ludology.htm Erişim Tarihi: 17.10.2020. 
Gaming in Turkey. (2019). Türkiye Oyun Sektörü Raporu. Gaming in Turkey.

Garrelts, N. (2005). Negotiating the Digital Game/Gamer Intersection. Digital Gameplay Essays on the Nexus of Game and Gamer içinde Ashe County: McFarland \& Company.

Güngör, N. (2020). İletişim: Kuramlar, Yaklaşımlar. Ankara: Siyasal Kitabevi.

Gür, M. R. (2018). Çok Oyunculu Dijital Oyunlarda Oyun Oynama Pratikleri: Moba ve Mmorpg Oyunlar Üzerine Karşılaştırmalı Bir İnceleme. (Yüksek Lisans Tezi). YÖK Ulusal Tez Merkezi. 525125.

history.com. (2019, 06 10). Video Game History. Erişim Adresi: www.history.com:

https://www.history.com/topics/inventions/history-of-videogames\#section_6 Erişim Tarihi: 21.10.2020.

Huizinga, J. (2018). Homo Ludens Oyunun Kültürel İşlevi Üzerine Bir İnceleme. Eskişehir: Dorlion.

İgit, A. (2019). Dijital Oyunlarda Empatik İletişim. Ankara: Nobel.

Işığan, A. İ. (2012). Etkileşimsellik Sorunu Çerçevesinde Dijital OyunAnlatı İlişkisi. (Doktora Tezi). YÖK Ulusal Tez Merkezi. 330875.

Juul, J. (1998). A Clash between Game and Narrative. Digital Arts and Culture Conference. Bergen. Erişim Adresi: https://www.jesperjuul.net/text/clash_between_game_and_narrativ e.html Erişim Tarihi: 24.10.2020.

Juul, J. (2001). Games Telling Stories? Game Studies 1(1), 1-1. Karadeniz, O. Ö. (2017). Oyun İncelemelerinde Ludoloji - Narratoloji Tartışması ve Alternatif Kuramsal Arayışlar. Galatasaray Üniversitesi İletişim Dergisi 27, 57-78.

Kaya, G. (2019). Re-Imagining "The East": Digital Games, NeoOrientalism and Representation of the Other in Military Shooter Games. (Master's Thesis). YÖK Ulusal Tez Merkezi. 586960.

Kline, S., Dyer Witheford, N. \& Peuter, G. (2003). Digital Play: The Interaction of Technology, Culture and Marketing. Quebec: McGillQueen's University Press.

Konzack, L. (2002). Computer Game Criticism: A Method for Computer Game Analysis. (Düz.). F. Mayra Proceedings of Computer Games 
and Digital Cultures Conference içinde Tampere: Tampere University Press.

Kürkçüoğlu, D. P. (2019). Varlık Alanı Olarak Dijital Oyunlar ve Sanal Nesneler. (Yüksek Lisans Tezi). YÖK Ulusal Tez Merkezi. 590076.

Landers, R. N. \& Bauer, K. N. (2015). Quantitative Methods and Analyses for the Study of Players and their Behaviour. (Düz.). P. Lankoski \& S. Björk içinde Game Research Methods: An Overview. ETC Press.

Lankoski, P. \& Björk, S. (2015). Introduction. Game Research Methods. içinde ETC Press.

Lieberoth, A. \& Roepstorff, A. (2015). Mixed Methods in Game Research. (Düz.). P. Lankoski \& S. Björk içinde Game Research Methods: An Overview. ETC Press.

Lupton, J. (2018 - B, 07 04). A Brief History of: The Sony Playstation 2. Erişim Adresi: funstockretro.co.uk: https://www.funstockretro.co.uk/news/a-brief-history-of-theplaystation-2/ Erişim Tarihi: 14.12.2020.

Marczak, R. \& Schott, G. R. (2015). Audio Visual Analysis of Player Experience. (Düz.). P. Lankoski \& S. Björk içinde Game Research Methods: An Overview. ETC Press.

Murray, J. (2005). The Last Word on Ludology v Narratology in Game Studies. DIGRA 2005. Vancouver.

Murray, J. H. (2016). Hamlet on the Holodeck. New York: The Free Press. Murray, J. H. (2016). Hamlet on the Holodeck the Future of Narrative in Cyberspace. New York: The Free Press.

Newzoo. (2019). The New Reality For Mobile Gaming. Newzoo.

Newzoo. (2020). 2020 Global Games Market Report. Newzoo.

Nieborg, D. B. \& Hermes, J. (2008). What is Game Studies Anyway?. European Journal of Cultural Studies 11(2), 131-147.

Playstation. (2020). PlayStation 5. Erişim Adresi: www. playstation.com: https://www.playstation.com/tr-tr/ps5/ Erişim Tarihi: 25.10.2020.

Sağlam, M. (2019). Dijital Oyunların Öznel İyi Oluşa Etkisi: Y Kuşağına Yönelik Bir Araştırma. (Doktora Tezi). YÖK Ulusal Tez Merkezi. 541443.

Sayılgan, Ö. (2014). Etkileşimli Drama Olarak Dijital Oyunlar ve 'Etkileşimliliğin İdeolojisi' Bağlamında Oyuncu Alımlama Pratikleri. 
(Doktora Tezi). Erişim Adresi:

http://katalog.istanbul.edu.tr/client/tr_TR/default_tr/search/detailno nmodal/ent: $\$ 002 f \$ 002 f S D \_I L S \$ 002 f 0 \$ 002 f S D \_I L S: 1335332 / o n e ? q$ $\mathrm{u}=$ Sayılgan $\% 2 \mathrm{C}+$ Özge $. \& \mathrm{ic}=$ true $\& \mathrm{ps}=300$

Sepetçi, T. (2017). Dijital Oyunlar, Dijital Oyuncular: Karşı Hegemonya Pratikleri ve Sosyal Etkileşim. (Doktora Tezi). YÖK Ulusal Tez Merkezi. 475245.

Sezen, T. İ. \& Sezen, D. (2011). Dijital Oyun Tarihinin Dönüm Noktaları. (Düz.). G. Ünal \& U. Batı içinde Dijital Oyunlar: Kendi Dünyanda Yaşa, Bizimkinde Oyna. İstanbul: Derin Yayınları.

Shipman, E. (2017). Influential Aspects on Purchase Frequency of Video Games Among Millennials in Turkey. (Master's Thesis). YÖK Ulusal Tez Merkezi. 496012.

Sönmez, A. A. (2019). A Taxonomy Proposal for Video Games with a Focus on Visualization Modes. (Master's Thesis). YÖK Ulusal Tez Merkezi. 598955.

Stadia. (2020). About Stadia. Erişim Adresi: stadia.google.com: https://stadia.google.com/ Erişim Tarihi: 25.10.2020.

Statista. (2020, 06). Number of video gamers worldwide 2015-2023.

Erişim Adresi: www.statista.com:

https://www.statista.com/statistics/748044/number-video-gamersworld/ Erişim Tarihi: 25.10.2020.

Sürücü, A. (2020). Animal Cruelty in Video Games: An Ethical Investigation. (Master's Thesis). Erişim Adresi: https://www.researchgate.net/publication/346085551_Animal_Cruel ty_In_Video_Games_An_Ethical_Investigation

Şengün, S. (2013). Six Degrees of Video Game Narrative: A Classification for Narrative in Video Games. (Yüksek Lisans Tezi). YÖK Ulusal Tez Merkezi. 333952.

Şentürk, L. \& Aktaş, E. (2014). Yabancı Dil Olarak Türkçe Öğretiminde Oyunların Başarıya Etkisi. Türkçe Öğretiminde Kuramsal ve Uygulamalı Çalışmalar içinde Ankara: Pegem Akademi Yayınları.

Şimşek, A. \& Şimşek, H. (2018). Nitel Araştırma Yöntemleri. Ankara: Seçkin Yayınları.

Taşkıran, Y. (2019). Dijital Oyunlarda Oryantalist Söylem. (Yüksek Lisans Tezi). YÖK Ulusal Tez Merkezi. 594874. 
Tezel, Y. (2019). Bilgisayar Oyunları Tarihi. İstanbul: Sokak Kitapları.

Wallner, G. \& Kriglstein, S. (2015). An Introduction to Gameplay Data Visualization. (Düz.). P. Lankoski \& S. Björk içinde Game Research Methods: An Overview. ETC Press.

Web of Science. (2020, 10 20). Search Results. Erişim Adresi: apps.webofknowledge.com: https://apps. webofknowledge.com/summary.do?product=WOS\&sear ch_mode $=$ GeneralSearch\&qid $=18 \&$ SID $=$ C1tO6DHnBcGcBgphaVf Erişim Tarihi: 20.10.2020.

Wills, J. (2019). Gamer Nation. Baltimore: Johns Hopkins University Press. Wolf, M. J. (2012). Before the Crash: Early Game History. Detroit: Wayne State University Press.

Worldometer. (2020, 12 16). Current World Population. Erişim Adresi: worldometers.info: https://www.worldometers.info/worldpopulation/ Erişim Tarihi: 16.12.2020.

Xbox. (2020). Yepyeni Xbox Series. Erişim Adresi: www.xbox.com: https://www.xbox.com/tr-TR/consoles/xbox-series-x Erişim Tarihi: 25.10.2020.

Yavuz, N. Z. (2018). Challenging The Influence of Interactivity on Narrative Structures in Digital Games. An Analysis of Adventure Genres. (Master's Thesis). Erişim Adresi: http://academicrepository.khas.edu.tr/handle/20.500.12469/2595

Yengin, D. (2010). Dijital Oyunlarda Şiddet Kavramı: Yeni Şiddet. (Doktora Tezi). YÖK Ulusal Tez Merkezi. 273493.

Yiğitoğlu, V. (2018). Oyun Değer Dijital Oyunlar ve Kullanıcılar Üzerine Bir İnceleme: To the Moon Örneği. (Doktora Tezi). Erişim Adresi: https://openaccess.maltepe.edu.tr/xmlui/bitstream/handle/20.500.1 2415/406/10209093. pdf. pdf?sequence $=1$ \&isAllowed $=y$

Yıldız, M. E. (2019). Derin Oyun Olarak Futbol Video Oyunları: Trabzon'da Futbol Video Oyun Kültürleri Üzerine Etnografik Bir Değerlendirme. (Doktora Tezi). YÖK Ulusal Tez Merkezi. 622864.

Yükseköğretim Kurulu. (2020, 10 20). Erişim Adresi: https://tez.yok.gov.tr/UlusalTezMerkezi/tezSorguSonucYeni.jsp Erişim Tarihi: 20.10.2020. 
GENİŞLETİLİ̧̧ ÖZET: Dijital oyunlar insan yaşamında giderek artan bir öneme sahip olmakta, bu süreçte farklı disiplinler tarafından akademik çalışmalara konu olmaktadır. Literatürde dijital oyunların hangi disiplinlerle, hangi kuramsal yaklaşım ve kavramsal çerçevelerle, hangi yöntemlerle incelenmesi gerektiğine dair süregelen bir fikir uyuşmazlığı bulunmaktadır. Dijital oyunların daha iyi anlaşılması için, bilim içerisinde hiyerarşik bir düzene oturması, yöntem ve yaklaşımlarının belirlenmesi önem arz etmektedir. Bu araştırmanın amacı, Türkiye' de iletişim biliminde dijital oyunlara yönelik bilimsel çalışmaların betimsel bir analizini yapmak, bulgular ve sonuçlarla literatüre katkı sağlamaktır. Araştırmada şu sorulara yanıt aranmaktadır: Dijital oyunlara dair bilimsel çalışmalarda araştırma odakları, kuramsal yaklaşım ve kavramsal çerçeveler, bilimsel yöntemler nelerdir? Literatürdeki dijital oyunların incelenmesine yönelik anlatım bilimi - ludoloji tartışmasında Türkiye'deki yaklaşım nasıldır? Araştırmanın örneklemi olasılığa dayalı olmayan örnekleme tekniklerinden amaçsal örnekleme ile seçilmiştir. Yükseköğretim Kurulu Ulusal Tez Merkezi Veri Tabanında; çalışmasını "iletişim bilimleri" alanında kategorize eden araştırmacıların tezleri içinde, "dijital oyunlar" ve "video oyunları" ifadelerini başlığında içeren 21 tez örneklemi oluşturmaktadır. Çalışmanın birinci bölümünde geleneksel ve dijital oyun kavramları açıklanmış, dijital oyunların tarihçesindeki önemli noktalar aktarılmış ve 2020 yılı itibariyle dijital oyunlardaki son gelişmeler ve kullanım verileri paylaşılmıştır. Çalışmanın ikinci bölümünde, dijital oyunlarla ilgili akademik çalışmalara dair literatürdeki görüşlere yer verilmiş; dijital oyunların incelenmesinde kuramsal yaklaşımlar, önerilen yöntemler ve disiplin tartışmaları açıklanmıştır. Ardından Türkiye'de dijital oyunlara ilişkin akademik çalışmalara dair istatistiksel bilgiler paylaşılmıştır. Çalışmanın üçüncü bölümünde "21 başlıklı tez analiz tablosu" oluşturulmuştur. Tabloyu oluşturan başlıklar: "Araştırmanın yılı, yazarı, yazarın ana bilim dalı, araştırmanın başlığı, türü, dili, araştırmanın oyun ya da oyuncuya odaklanması, odaklanılan konu, konu teması, konu temasının olumlu ya da olumsuz oluşu, araştırmanın amacı, araştırmanın kavramsal çerçevesini oluşturan başlıklar, araştırmanın kuramsal yaklaşımı, bu kuramın kategorisi (örneğin edebiyat kuramı ya da politik kuram), araştırmacının uygulama kısmında kullandığı yöntem, yöntem türü, veri toplama aracı, araştırmanın örneklemi, oyunların anlatı ya da yapısal yönüne odaklanma, ulaşılan sonuçlar, sonucun olumlu ya da olumsuz durumu" olmak üzere 21 tanedir. Tablo vasıtasıyla toplanan veriler betimsel olarak analiz edilmiştir. Betimsel analizde Şimşek ve Yıldırım'ın aşama önerileri kullanılmıştır. Çalışmaların 10'unun oyuna, 9'unun oyuncuya, 2'sinin hem oyun hem oyuncuya odaklandığı ortaya çıkmıştır. Araştırma konuları "Oyunların içinde yer alan bir kavram", "Oyunların bir etkisi" ve "Oyunun yapısına dair" olmak üzere 3 kategoride toplanmaktadır. Çalışmaların 5 tanesinin olumsuz konulara (Şiddet, neo/oryantalizm, propaganda) odaklanmış olduğu görülmektedir. 5 Çalışma ise olumlu konulara odaklanmıştır. Bu konular; Bilişsel yetenek, sosyal etkileşim, 
öznel iyi oluş, empati, mod yazılımlardır. Ele alınan çalışmaların 11 tanesinin araştırma konusu nötr olarak değerlendirilmiştir. Bu konular: Anlatı unsurlarının, oyunların nasıl alımlandığının, satın almaya etken faktörlerin, oynama motivasyonlarının, oyun yapısının ve oyun kültürünün sorgulanması gibi konulardan oluşmaktadır. İletişim bilimi alanında dijital oyunlar üzerine çalışmalar yapan araştırmaların; edebiyat, felsefe, antropoloji, pazarlama, siyaset, sosyoloji gibi farklı disiplinlerin kuramlarından yararlandığı görülmektedir. Açık bir şekilde ana kuramsal yaklaşımın belirten tezler içerisinde, iletişim biliminde sıklıkla çalışılan kuramların kullanılmadığı görülmektedir. Araştırma kapsamındaki 21 tezin 13'ü nitel araştırma, 4'ü nicel araştırma, 4'ü karma araştırma yöntemini kullanmıştır. Tüm çalışmalar içerisinde 7 anket, 4'er derinlemesine görüşme ve göstergebilim, 3'er içerik analizi, araştırmacının kendi geliştirdiği metot, başka araştırmacının geliştirdiği metot ve 1'er tane de test, gözlem, söylem analizi, etnografi yöntemi kullanılmıştır. Çalışma kapsamına alınan 21 tezin 10 tanesi literatürdeki anlatım bilimi ve ludoloji arasındaki fikir ayrılıklarına hiç değinmemiştir. Tezler içerisinde, söz konusu tartışmaya yer veren ancak bu konuda kendi görüşünü bildirmeyen 6 çalışma bulunmaktadır. 3 Yazar, oyunların incelenmesinde bütüncül yaklaşım ve yöntemlerin kullanılması gerektiğini belirtmiştir. Araştırma sonuçlarından hareketle; dijital oyunların içerdiklerinin ve etkilerinin nasıl alımlandığının daha çok incelenmesi gerektiği söylenebilir. Oyuncuya odaklanan çalışmalara ağırlık verilmeli ve oyunların nasıl etkiler yarattığı daha iyi anlaşılmalıdır. Araştırmanın odaklandığı konuya bağlı olarak, geleneksel oyun kavramını ve onun özelliklerini kavramsal çerçeve içerisinde tutmak ya da tutmamak seçenek olarak kalmalı, bir zorunluluk olmamalıdır. Dijital oyunların yeni medya düzeni içerisindeki konumuna odaklanmış çalışmaların eksikliği hissedilmektedir. Bu sebeple oyun yayıncılığının yeni medya ile ilişkilendirildiği çalışmaların artırılması gerekmektedir. Büyük bir kültür endüstrisi olan dijital oyun sektörünün eleştirel ekonomi politik bakış ile incelenmediği görülmektedir. Bu eksikliği kapatmak adına dijital oyunların eleştirel ekonomi politik bakış açısıyla incelenmesi gerekmektedir. Böylesine büyük bir fenomenin içerdiklerinin bir sınırı yokken, onu inceleyecek disiplinlerin ve kuramsal perspektiflerin sınırlanması doğru değildir. Bununla birlikte Türkiye'de dijital oyunlara dair bilimsel bir bütünlük sağlamak adına, işin daha çok teknik kısmına odaklanan üniversite bölümlerinin, oyun üretiminin yanı sıra oyunların incelenmesine odaklanması ve bu konuda yol haritaları oluşturması önem arz etmektedir. Literatüre farklı bakış açılarından yeni yöntemler katmak adına, derinlemesine bilimsel araştırmalar olan doktora tezleriyle de metot geliştirme çalışmaları yapılmalıdır. Oyundaki anlatılara odaklanırken diğer yandan oyunu bir film ya da romandan ayıran özellikleri de ihmal etmeyen çalışmalara ağırlık verilmelidir. Dijital oyunların olumsuz özellik ve etkilerinin önlenmesi ve etkilerinin azaltılması için, toplumda "oyun okur yazarlığı" bilincinin oluşturulması gerekmektedir. 
EXTENDED ABSTRACT: Digital games have an increasing importance in human life and are subject to academic studies by different disciplines in this process. There is an ongoing disagreement in the literature regarding which disciplines, theoretical approaches and conceptual frameworks, and methods should be studied in digital games. In order to better understand digital games, it is important to settle in a hierarchical order within science and to determine their methods and approaches. This research aims to do a descriptive analysis of digital games in the discipline of communication sciences in Turkey and contributing to the literature with the results. The research seeks answers to the following questions: What are the research focuses, theoretical approaches and conceptual frameworks, scientific methods in scientific studies on digital games? The sample of the study was chosen by purposeful sampling, one of the nonprobabilistic sampling techniques. In the Council of Higher Education Thesis Center Database; Among the theses of the researchers who categorize their study in the field of "communication sciences", 21 theses including the terms "digital games" and "video games" constitute the sample. In the first part of the study, traditional and digital game concepts are explained, important points in the history of digital games are explained, and the latest developments and data in digital games as of 2020 are given. In the second part of the study, the opinions in the literature about academic studies on digital games are given; Theoretical approaches, suggested methods and discipline discussions in the study of digital games are explained. Then statistical information pertaining to the academic study of digital games in Turkey are given. In the third part of the study "Thesis analysis table with 21 titles" was created. This table contains the following headings: "The year and writer of the research, the researcher's main discipline, the title, type and language of the research, focus subject (the game or player?), the topic of focus subject, topic theme, pros and cons of topic theme, purpose of the research, the titles that form the conceptual framework of the research, the theoretical approach of research, the category of this theory (e.g. literary theory or political theory), method, method type, data collection tool used by the researcher in the application part, the sample of the research, focusing on the narrative or structural aspect of the games, the results achieved, the positive or negative state of the results. The data collected through the table were analyzed descriptively. In the descriptive analysis, Şimşek and Yıldırım's stage suggestions were used. It was revealed that 10 of the studies focused on the game, 9 on the player, and 2 on both the game and the player. Research topics are categorized under three categories: "A concept within games", "An effect of games" and "About the structure of the game". It is seen that 5 of the studies focused on negative issues (violence, neo / orientalism, propaganda). Five of the studies focused on positive issues. These issues; Cognitive ability, social interaction, subjective well-being, empathy, modding. The research subject of 11 of the studies was evaluated as neutral. These subjects are as 
follows: Narrative elements, questioning the effects, factors affecting the purchase, motivations to play, game structure and game Culture. Studies on digital games in the field of communication science benefit from the theories of different disciplines. These theories are as follows: Literature, philosophy, anthropology, marketing, politics, sociology. It is seen that the theories that are frequently studied in communication science are not used among the theses that clearly state the main theoretical approach. Of the 21 theses within the scope of the research, 13 used qualitative research, 4 quantitative research, 4 mixed research method. In all studies, 7 questionnaires, 4 in-depth interviews and semiotics, 3 content analysis, 1 each researcher's own method, other researcher's method, test, observation, discourse analysis, ethnography method were used. Ten of the 21 theses included in the study did not mention the differences of opinion between narratology and ludology in the literature. There are 6 studies in the theses that include the aforementioned discussion but do not express their opinion on this subject. 3 Researchers stated that holistic approaches and methods should be used in examining games. Based on the research results; It can be said that the content and effects of digital games should be examined more. Studies focusing on the player should be increased and the effects of games should be better understood. Depending on the focus of the research, keeping or not keeping the traditional game concept and its features within a conceptual framework should remain as an option and should not be an obligation. There is a lack of studies focused on the position of digital games in the new media order. For this reason, it is necessary to increase the studies in which game streaming is associated with new media. It is seen that the digital game industry, which is a large cultural industry, is not examined with a critical political economy perspective. In order to fill this gap, digital games should be examined from a critical political economy perspective. While there is no limit to the implications of such a great phenomenon, it is not correct to limit the disciplines and theoretical perspectives that will examine it. However, to ensure that the scientific integrity of a digital game in Turkey, universities must decide on how to research the games. In order to add new methods from different perspectives to the literature, method development studies should be carried out with doctoral dissertations, which are in-depth scientific researches. While focusing on the narratives in the game, on the other hand, studies that do not neglect the features that distinguish the game from a movie or a novel should be focused on. In order to prevent the negative features and effects of digital games and to reduce their effects, it is necessary to create a "game literacy" awareness in the society. 